\title{
Hat-e a korrupció a választókra? - egy bayes-i ökonometriai elemzés ${ }^{1}$
}

\section{TÓTH ANDRÁS² - BARCZIKAY TAMÁS³ - ATANASZOV DÁVID ${ }^{4}$}

\begin{abstract}
ABSZTRAKT
A tanulmány korrupciókutatási szempontból vizsgálja a 2010 és 2016 közötti magyar politikai élet napirendállítási törekvéseit. A rendelkezésre álló adatok segítségével egy hatéves idöszak havi adatsorai alapján, eltérô statisztikai módszerekkel becsüljük, hogy volt-e hatása a korrupció proxyként használt európai uniós források kihelyezésének a kormánypárt támogatottságára. Az alkalmazott bayes-i vektor autoregresszió eredményei nem szolgáltatnak bizonyítékot a hipotézisre, mely szerint az EU-támogatások növekedésével járó korrupciónövekedés csökkenti a kormányzópárt népszerüségét a teljes szavazókorú népességen belül.

KULCSSZAVAK: korrupció, ökonometriai modell, bayes-i vektor autoregresszió, szavazói magatartás
\end{abstract}

\section{ABSTRACT}

Does the corruption affect to the voters? - a Bayesian econometric analysis

The study examines the agenda-setting aspirations of Hungarian political life between 2010 and 2016 from a corruption research perspective. Using the available data, we estimate, based on the monthly data series of a six-year period, using different statistical methods, whether the allocation of European Union funds used as a proxy for corruption had an impact on the support of the ruling party. The results of the applied Bayesian vector autoregression do not provide evidence for the hypothesis that the increase in corruption associated with the increase in EU subsidies reduces the popularity of the ruling party among the entire voting population.

KEYWORDS: corruption, econometric model, bayesian vector autoregression, voting preferences

\section{Bevezetés}

A rendszerváltás utáni korrupció eredete visszanyúlik a késői Kádár-korba (Lengyel, 1998), melynek forrása talán a korrupt privatizáció, amely során először tör-

${ }^{1}$ A cikk az Emberi Erőforrások Minisztériuma ÚNKP-18-3 kódszámú Új Nemzeti Kiválóság Programjának támogatásával készült. A szerzők ezúton is szeretnék megköszönni a segítséget.

${ }^{2}$ Eötvös Loránd Kutatási Hálózat Társadalomtudományi Kutatóközpont Politikatudományi Intézet, Magyar Tudományos Akadémia Kiváló Kutatóhely; e-mail: tothandhu@gmail.com

${ }^{3}$ Eötvös Loránd Kutatási Hálózat Társadalomtudományi Kutatóközpont Politikatudományi Intézet, Magyar Tudományos Akadémia Kiváló Kutatóhely; e-mail: Barczikay.Tamas@tk.mta.hu

${ }^{4}$ EPAM Systems, atanaszov.david@gmail.com 


\section{TANULMÁNY}

tént meg a politikai hatalom gazdasági hatalommá változtatása (Balázs 1991). Vásárhelyi Mária már 1998-ban felhívta a figyelmet arra, hogy a korrupció az oka az állami intézményekbe vetett bizalom csökkenésének és a politikai apátiának. Különösen igaznak tartotta ezt azért, mert a politikai elit alkotja meg a kereteket jogszabályok és stratégiák formájában a korrupció elleni fellépésre, azonban ezeket a szabályokat csak a „kisember” kis korrupciójára alkalmazzák, miközben a politikai elit büntetlenül szegi meg az általa felállított szabályokat.

A rendszerváltás utáni magyar választások történetében kulcsszerepet játszottak a korrupciós ügyek (Balázs 2002). A Horn-kormány 1998-as választási vereségében a Tocsik-ügy néven elhíresült botránynak volt kiemelkedő szerepe (Révész 2008). A 2002-es választási kampányban az SZDSZ a Lop-Stop jelszóval kampányolt sikeresen, hogy aztán 2004-ben a koalíciós partner miniszterelnök rombolja le a párt maradék tekintélyét azzal a váddal, hogy tele van korrupciós ügyekkel (Fábián et al. 2010). A 2010-es választások előtti korrupciós botrányok (a hírhedt Nokiás doboz ügy) kétségkívül hozzájárultak a Fidesz sikeréhez (Németh et al. 2011). A 2010-es kormányváltás óta sem csendesedett el a korrupció körüli politikai harc. Az ellenzéki pártok egyik legfontosabb üzenete a kormánypárti politikusok korrupciós ügyeinek felhánytorgatása. Ugyanakkor, a kormánypártok 2014-es választási győzelmének fontos mozzanata volt az egyik vezető ellenzéki politikus látványos letartóztatása korábbi állítólagos korrupciós ügye miatt.

A témával foglalkozó tudományos irodalom a korrupció folyamatos növekedését jelzi (Ligeti 2016), melynek növekedésével a közvélemény is tisztában van. Az Európai Bizottság közvélemény-kutatásai is alátámasztják, hogy a választópolgárok egyre súlyosabb problémának látják a korrupciót. 2017-ben a megkérdezettek 86\%-a vélte úgy, hogy Magyarországon jelen van a korrupció, és 58\%-uk gondolta úgy, hogy a korrupció szintje súlyosbodott az elmúlt három évben. A magyar lakosság jóval magasabbnak ítélte meg a korrupció jelenlétét, mint az uniós átlag (68\%, illetve 43\%). A magyarországi korrupciós fertőzöttség megítélési aránya a harmadik legmagasabb az EU-ban, Ciprus és Spanyolország után. A népesség 69\%-a véli úgy, hogy ezt a típusú korrupciót nem üldözik kellőképpen (amely szintén az egyik legmagasabb arány az EU-ban), és csak 19\%-a gondolja fordítva. A társadalom mindössze 4\%-a vélekedett úgy, hogy az elmúlt három évben csökkent a korrupció szintje, 33\% pedig azt gondolta, hogy ez változatlan maradt. Ami a politikai korrupciót érinti, 77, illetve 76\%-a a magyaroknak úgy vélekedik, hogy a korrupció jelen van a helyi, illetve az országos közintézményekben. Vagyis meglepően magasnak ítélik meg a politikai korrupció mértékét (Civitas 2018: 11).

Egy, az intézményesített korrupciót vizsgáló tanulmány arra a következtetésre jutott, hogy Magyarországon a közpénzek illetéktelen megszerzésére szakosodott hálózatok működnek, amelyek szerepe túlmutat a „szokásos” 10-15\%-os korrupciós járadék megszerzésén (Jancsics - Jávor, 2012). Az Európai Bizottság 2015. évi országjelentése megállapította, hogy a „közszférában a döntéshozatalt és a közbeszer- 


\section{TANULMÁNY}

zéseket befolyásoló korrupció továbbra is aggodalomra ad okot”. A korrupció növekedését a Transparency International 2017. évi jelentése is rögzítette. A Civitas Intézet (2018) külön könyvet adott ki a legfontosabb korrupciós esetekről.

A tudományos eredmények is azt mutatják, hogy aggasztóan magas és növekszik a korrupció mértéke Magyarországon (Transparency International 2008). Különös gond az intézményesedett politikai korrupció, mely növekedése nyomán Szántó Zoltán hálózatosodott (2011), Ligeti Miklós (2019) rendszerszintű korrupcióról beszél. Innes (2014) az állam foglyul ejtésének új formájáról, Magyar (2013) pedig egyenesen rendszerszintű korrupcióról, maffiaállamról értekezik. Magyar szerint a maffiaállami rendszerszintű korrupció jellemzője az, hogy a végrehajtó hatalom az intézményi környezet szétzilálásával megteremti saját maga számára az ellenőrizetlen cselekvés szabadságát és ezzel a rendkívül széles mozgástérrel visszaélve a hatalmon lévők és szövetségeseik érdekeit juttatja érvényre. A korrupció rendszerszintűvé válásával az illetéktelen előnyöket célzó döntések a központi állam cselekvéseiben is megjelennek.

Az intézményesített korrupció egyik legfontosabb területe az európai uniós támogatások elosztása. Az európai uniós pénzek elosztásának folyamatát a hálózatosodott csalás egyik terepeként mutatja be Szántó és szerzőtársainak tanulmánya (2011). A Transparency International (2015) külön tanulmányban foglalkozott az európai uniós pénzek körüli korrupcióval. A jelentés kiemeli az uniós pénzek forrásbőségét, ami különlegesen nagy korrupciós teret generál (Transparency International 2015). Az uniós projektek esetében a TI úgy találta, hogy a támogatás-elbírálás alábbi szakaszai különösen alkalmasak arra, hogy korrupció terepei legyenek: 1) Indokolatlanul kiválasztott fejlesztési célok; 2) Befolyás érvényesítése a projektkiválasztási folyamatban; 3) Pályázatok kedvező elbírálása magas arányú pályázatírói díjazás ellenében; 4) Pályázatok kedvező elbírálása túlárazott szolgáltatás igénybe vételéért cserébe; 5) Piaci árnál lényegesen magasabb árral elszámolt költségek; 6) Egy konkrét ajánlattevőre szabott közbeszerzés; 7) A közbeszerzési kiírás „finomhangolása” a piac korlátozása céljából; 8) Megbízás odaítélése saját erő juttatása ellenében.

A EU-s pályázatok korrupt jellege az egyik legtöbbet felvetett kérdés a magyar sajtóban. Ezt a hangulatot erősítették meg az OLAF vizsgálatai és a folyamatos hírek az EU büntető szankcióiról Magyarországgal szemben a nagyarányú korrupció miatt (Polyák 2018, Népszava 2018, Napi 2018). Az EU-s pénzek esetében a politikai korrupció lehetőségét elősegíti a döntési folyamatok központosítása, amely 2010 óta különösen erősödött (Transparency International 2008).

Tanulmányunkban arra keresünk választ, vajon a sajtóhírek és elemzők szerinti nagymértékű korrupció, amivel a választópolgárok döntő többsége is tisztában van, befolyásolja-e a kormánypártok támogatottságát, a választó polgárok politikai preferenciáit?

A tanulmány szerkezete a következő. Először áttekintjük a korrupcióval foglalkozó politológiai irodalom vélekedését a korrupció és a politikai népszerűség kapcso- 


\section{TANULMÁNY}

latáról. Ez alapján megfogalmazzuk hipotéziseinket. A tanulmány második részében empirikusan vizsgáljuk a korrupció és a politikai közvélemény időbeli alakulásának kapcsolatát. Ennek során bemutatjuk a felhasznált adatsorokat és azok statisztikai tulajdonságait. Ismertetjük a becslések elméletét, majd az elmélet és az eljárások alkalmazásával BVAR-modellt illesztünk az idősorokra és közöljük az eredményeket. Tanulmányunk konklúzióval zárul, melyben válaszolunk a hipotézisekre és felvázoljuk a kutatás folytatásának lehetséges irányait.

\subsection{Irodalom áttekintés:}

\section{a korrupció és a politikai népszerúség kapcsolata}

Az irodalomban a korrupció jelenségének leírása nem mindig egyértelmű. A szakirodalom általánosan elfogadott álláspontja szerint a korrupció azonos az egyéni haszonszerzéssel a hivatali hatalommal való visszaélés révén (Treisman 2000). Ennek a megfogalmazásnak (Rothstein 2008) azonban van egy sajátos hiányossága, miszerint nem fogalmazza meg, mit is jelent a hivatali hatalommal való visszaélés. Kurer (2005) és Rothstein (2008) szerint a korrupció fogalmába beletartozik az is, amikor a kormányzati pozícióban levő személy eltér a függetlenség elvétől és ennek révén szerez egyéni előnyt. Rothstein Mungiu és Pippidi (2006) tanulmányára hivatkozva a korrupció fogalomkörébe sorolja továbbá a klientizmust, patronázst, politikai előnyszerzést vagy nyújtást, és a harmadik fél diszkriminációját is. Della Porta és Vannucci (1997: 231-232) kifejezetten politikai korrupcióról beszélnek annak a jelenségnek a kapcsán, ha a hatalmat gyakorló személy visszaélve pozíciójával eltér az államigazgatásban elvárt érdekmentes döntéstől.

Bull és Newell $(1997,2003)$ szerint a politikai korrupció egyik legfontosabb formája az erőforrások allokációja a politikai párt érdekei szerint, amit angolul pork and barrel politikának hívunk. Magone (2003) és Papp (2019) egyaránt rávilágít, hogy az európai strukturális alapok jelentős forrásai a tág értelemben vett politikai korrupciónak, azaz pork and barrel politikának. Mint ahogy irodalom áttekintésünk kimutatja, a sajtó hírek és a magyarországi korrupcióval foglalkozó irodalom szerint feltehető, hogy nem csak politikai előnyszerzés figyelhető meg, hanem a tényleges anyagi haszonszerzés is.

A tudományos közvéleményben azonban vitatott kérdés az, hogy a korrupció megléte és észlelése mennyire befolyásolja a választási eredményeket. Ecker - Glinitzer - Meyer (2016) szerint a korrupció érzékelésének fontos szerepe van az éppen kormányzók megbüntetésében, leváltásában, míg Heidenheimer (2002) szerint elsősorban a választók haragját vonja maga után. Rosenstiel és Mitchell (2003) szerint a korrupció fontosságát a választók szemében aláhúzza a média szerepe, illetve az, hogy a média szívesen foglalkozik a témával. A Civitas Alapítvány Fekete könyve (2018) alapján a korrupció a „rossz kormányzás” legfontosabb jele, mert többnyire 


\section{TANULMÁNY}

együtt jár a jogállamiság megsértésével. Ezzel szemben sok szkeptikus véleménnyel is találkozhatunk.

Beck (1988), Beck-Stegmaier (2000), Klašnja és Tucker (2013), valamint Hazama (2017) megközelítésében a választópolgárok értékelésének az egyik legfontosabb komponense a gazdasági helyzet alakulása, melyet tipikusan a választások előtti egy év perspektívájából ítélnek meg, így a megelőző három év történései kevésbé fontosak. A szakirodalom ezt a jelenséget az utólagos eredmény értékelésen alapuló szavazásnak hívja (retrospective voting) (Lewis-Beck et al. 2013). Ezen felül a nemzeti politikai rendszerek sajátosságai (Charon 2011) és a sajtó hatása (Chang et al. 2010) megakadályozhatja a korrupció miatti felháborodás átalakulását kormányellenes szavazattá. Fontos tényező mindemellett a kormányzati korrupciót kifogásoló ellenzék hitelessége (Krause - Méndez 2009). Pavao (2018) érvelése szerint, ha a korrupció mélyen átjárja a társadalmat és általánosan jellemző mind az éppen kormányon levő politikusokra, mind a kormányzásból kiesett, éppen ellenzékben levőkre egyaránt, akkor könnyen elveszítheti a választók számára fontos megkülönböztető jellegét, melyből fakadóan nem válik választást motiváló tényezővé. Ehhez a problémakörhöz kapcsolódik a pártrendszer szerkezete is, amely csökkentheti vagy növelheti a választás lehetőségét (Xezonakis 2012).

Az irodalom egy ága azon vitatkozik, hogy vajon a két párt versengésére alapozott rendszer vagy a nyitottabb pártrendszer megengedő választási rendszerei a kedvezőbbek a korrupt politikusok túlélésének. A vitához kapcsolódóan az irodalom egyetértést mutat abban, hogy egy domináns párt által uralt rendszerben (Sartori 1976) az uralkodó párt megítélésében fontos szerepet játszik a korrupció asszociációja (Schleiter - Voznaya 2014), mivel az ilyen politikai helyzetben, ahol az ellenzék távol van a hatalomtól, a korrupcióért való felelősség egyértelmű és ezért a választók az uralkodó pártot okolják (Tavits 2007).

Szintén nem elhanyagolható, hogy a korrupció az állam melyik szintjén jelentkezik (Gingerich 2009). Manzetti és Wilson (2007) megítélése szerint a paternalista országokban, ahol erős a patrónus-kliens viszony beágyazottsága a társadalmi mindennapokban, a választók engedékenyebbek a korrupcióval szemben. Ehhez hasonló Weschle (2016) megállapítása, aki amellett érvelt indiai vizsgálatai alapján, hogy a választók inkább elítélik azt a típusú korrupciót, ami csak a korruptak meggazdagodását szolgálja, viszont azzal együtt tudnak élni, ha a korrupció egyben hozzájárul mások jobblétéhez, még ha ez egy választói csoport szavazatainak megvásárlását is jelenti. Ezt Weschle egy keynesianus multiplikátor hatásként interpretálta, mely magyarázza a félrenézést a jólét emelkedés tükrében. Fernández-Vázquez és szerzőtársai (2016) hasonló jelenséget fedeztek fel Spanyolországban: azoknak a polgármestereknek az újraválasztási esélyei voltak rosszabbak, akik nem osztottak vissza az állampolgárok nagyobb csoportjainak. North és szerzőtársai (2012) eredményei alapján, a politikai káosz utáni helyzetben a választók számára fontosabb a 


\section{TANULMÁNY}

rend helyreállítása, mint a korrupció. Ilyen poszt-káosz helyzetben Northék szerint a választók „fausti alkut” kötnek: a korrupciótól való eltekintés a rendért fizetett „ár”.

Látható a politológiai irodalom megosztottsága a korrupció választási eredményekre gyakorolt hatását illetően. A választók, mint láttuk, nem csak a korrupció törésvonala mentén szavaznak, sőt akár még a korruptabbnak tartott pártot is választhatják, ha a korrupció ellenére javul az életszínvonaluk, amit a kormányzó pártnak tudnak be, Linde - Erlingsson (2013), Lewis-Beck (2013) szintén amellett érvelnek, hogy a választás soha nem egydimenziós, s csak a korrupció megítélése egy elem a szavazók végső ítéletében. A zavart fokozza, hogy az egyes választások tapasztalatait feldolgozó empirikus kutatások is ellentmondásosak. Vannak, amelyek azt támasztják alá, hogy a szavazók büntetik a korrupciót (Peters - Welch 1980, Ferraz - Finan 2008, Banerjee 2014), mások szerint ez nem igaz (Golden 2010, Golden 2015, Winters 2013).

Az irodalom áttekintése rávilágít arra, hogy ugyan feltételezi (és részben normatív-erkölcsi alapon el is várja), hogy legyen kapcsolat a korrupció és a választási eredmény között, azonban az elméleti modellek és kutatási eredmények nem mutatnak egyértelmű képet. Ezt a kétértelműséget az is alátámasztja, hogy a források mennyi mentséget hoznak fel arra, hogy mégis miért szavaznak a választók nagy csoportjai (esetleg többsége) az általuk is korruptnak tartott politikusra, miközben tisztában vannak a korrupció negatív következményeivel. A korrupció választókra gyakorolt hatását azért is nehéz felmérni, mert az esettanulmányok esetében a kutatók jórészt visszamenőleg következtetik ki az okokat a választási eredmény ismeretében, és utólag értelmezik a szavazók döntését. Ebben az értékelésben mint láttuk, az utolsó év nagyobb szerepet játszik a megelőző évek eseményeinél. A kutatások másik nagy csoportja egy adott időpontban felvett kérdőív adatainak elemzésére támaszkodik és ennek révén próbálják felmérni a korrupcióhoz társított attitűdöket (Csapodi et al. 2011, Fenyvesi 2014, Keller 2014). A kérdőíves felmérések adatain alapuló egyszerű statisztikai számítások azonban nem képesek közvetlenül vizsgálni a korrupcióészlelés változásának időbeliségét, s emiatt egy adott későbbi pillanatban létező véleményt vetítenek vissza múltbeli események megítélésére.

\subsection{Hipotézisállítás}

Az irodalom összefoglalás kimutatta, hogy a korrupció politikai hatását vizsgáló tudományos irodalom megosztott abban a kérdésben, hogy döntő hatása van-e a választások kimenetelére a korrupcióval kapcsolatos ellenérzéseknek. Azt is láthattuk, hogy az eddig tipikusan alkalmazott survey alapú kutatási módszerek inkonkluzív, vagy egymásnak ellentmondó eredményeket hoztak annak a kérdésnek a megválaszolására, hogy vajon a nagyméretú és folyamatos korrupció észlelése befolyásolja-e a kormányzó pártok támogatottságát, a választó polgárok politikai preferenciáit. 


\section{TANULMÁNY}

Tanulmányunkban egy új becslési módszer alkalmazására teszünk javaslatot, a korrupció és a választási eredmények kapcsolatának vizsgálatára, ami segít az utólagos rekonstrukció veszélyeinek, illetve a kutatói szelektív értékelés csapdáinak elkerülésében. Ez a módszer a korrupcióészlelés véleményformáló hatásának megfigyelése a bayes-i vektor autoregresszió (BVAR) segítségével. A BVAR minden általunk felhasznált politikai és gazdasági idősorra becsül egy saját és az összes többi változó késleltetett értékein futtatott regressziót, majd a regressziók maradéktagjának segítségével szimulálja az egyes változókban bekövetkezett egységnyi sokkok hatását a teljes egyenletrendszerre. A sokkok hatását impulzusválasz függvényekkel (impulse response function - IRF) grafikusan ábrázolhatóvá tudjuk tenni.

Az általunk választott elemzési út lehetővé teszi a korrupció politikai preferenciákat befolyásoló hatásának időben visszamenőleges vizsgálatát, illetve a korrupció választói magatartásra gyakorolt hatásának elemzését. A cikk célja annak mérése, hogy vajon a korrupció mértékének változása kihat-e a választópolgári attitűdökre. Ahhoz, hogy ennek mérésére vállalkozni tudjunk, a következő alapfeltételezésekkel éltünk, a közgazdasági irodalomban általánosan alkalmazott ceteris paribus modellezés mintájára.

A korrupció forrásai közül egyedül az európai uniós pénzek elosztásához kapcsolódó megjelenést vizsgáljuk. Ennek az egy korrupciós forrás kiválasztásának metodológiai okai vannak: az európai uniós pénzek kiáramlása mérhető folyamat. Másrészt a GDP 4-5\%-át jelentő európai uniós források elosztása az egyik legnagyobb forrása az intézményes korrupciónak az irodalomszemle szerint. Köztudásnak tekinthető, hogy az uniós támogatások elosztása korrupcióval jár, amit alátámasztanak nemcsak a sajtóhíradások, tudományos elemzések, de a politikai pártok egymás elleni vádaskodásai és az EU-hatóságok a médiában és a nyilvánosságon széleskörüen ismertetett jelentései is. A korrupcióról szóló híradások és a mindenhol hallható pletyka szerint szinte köztudásnak számít, hogy van egy „korrupciós állandó”, vagyis a közpénzek elköltésénél feltételezetten 20\% körüli összeg az, amit a politikusok visszakérnek személyes vagy politikai célokra. A sajtóban számtalan cikk található, ami erről a 20\%-os, általunk korrupciós állandónak elnevezett járadékról nyíltan beszél (lásd például Civilhetes 2016, Origo 2018). Az EU-s pénzek elosztása centralizált, a kormányzat felelősségi körébe tartozó folyamat, ezért tisztán látható a választópolgárok számára a kormányzat felelőssége. Az EU-s támogatások elosztási mechanizmusa számtalan feltárt korrupciós lehetőséget jelent, amit az irodalom áttekintésekor bemutattunk.

Ezen tényezők alapján az EU által biztosított források elosztásának időbeli alakulását, a korrupció mértékét jelző indikátornak vettük. Pontosabban az EU-s pénzek országba áramlásának mértékét a korrupcióváltozás indikátorának tekintjük. Az egységnyi forráskiáramlás sokkja a modellben közvetlenül hat a közvélemény-kutatások által mért választói preferenciák arányára. 


\section{TANULMÁNY}

Elemzésünkben azt vizsgáljuk bayes-i vektor autoregresszió alkalmazásával, hogy az EU-s pénzek beáramlásának üteme hatással van-e a választópolgárok politikai választására?

A bayes-i vektor autoregressziók a társadalomtudományokban gyakran alkalmazott OLS-regresszióval ellentétben nem egy darab, hanem változónként egy egyenletet becsülnek és az összes többi változó késleltetését is tartalmazzák. A számítás bonyolultsága miatt, a hagyományos módon nem értelmezhető időben lejátszódó folyamatok impulzusválasz függvények segítségével grafikusan interpretálhatóak. Az impulzusválasz függvények megmutatják, hogyha az egyik változóban egy egységnyi sokk, azaz valamilyen irányú változás történik, akkor a többi változó arra időben hogyan reagál. Egy három idősort tartalmazó BVAR esetén kilenc impulzusválasz függvényt becsülhetünk, mivel a változó a saját késleltetett értékein keresztül önmagára is hat.

1. ábra. A Fidesz (1. sor 2. oszlop) és a preferenciával nem rendelkezők (1. sor 3. oszlop) arányának változása, addicionális EU-s erőforrás beáramlásának hatására
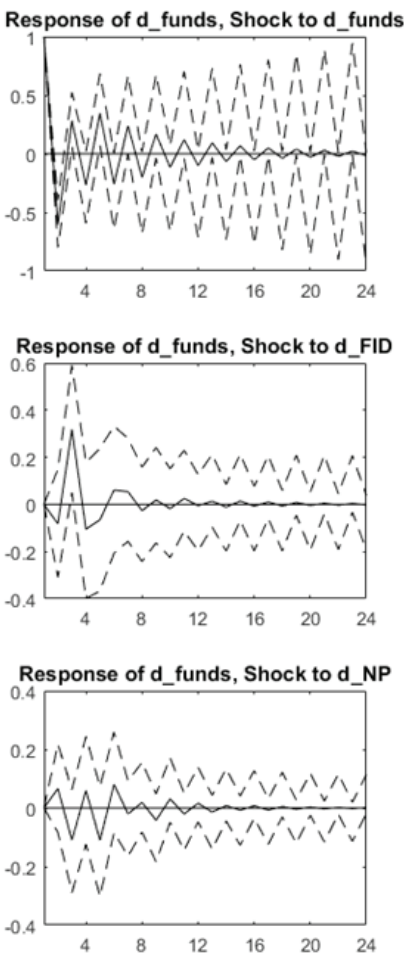

Forrás: Saját szerkesztés
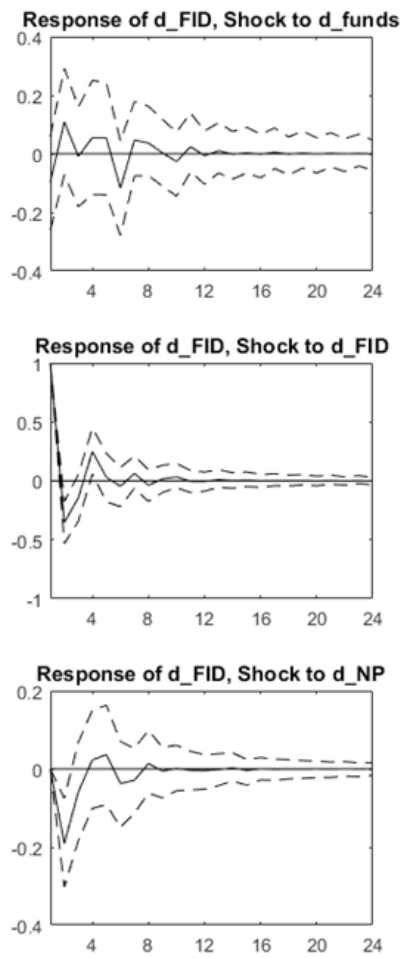
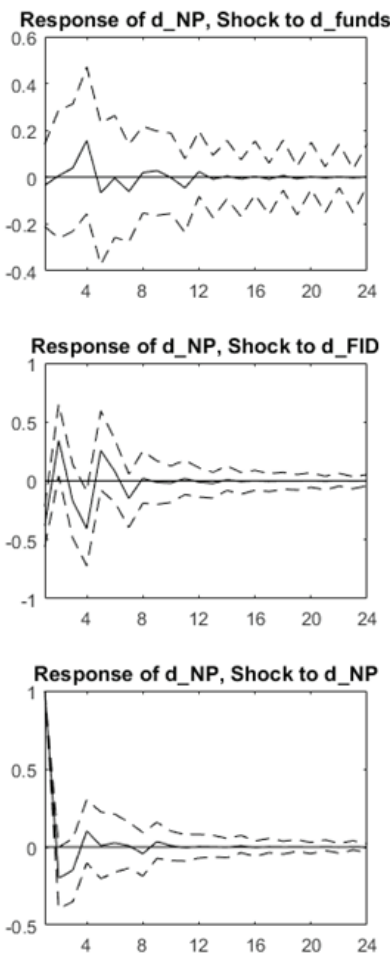


\section{TANULMÁNY}

Az IRF értelmezését az 1. ábrán keresztül mutatjuk be. A modell egyenletei a Fidesz támogatottságának és a preferencia nélküli szavazókorúak társadalomban mért arányát, valamint korrupció proxyként az országba beáramlott EU-s források millió euróban mért mennyiségét tartalmazzák a 2010 és 2016 közötti időszakban. Az 1. ábra alapján egy egységnyi támogatás beáramlása a Fidesz és a pártpreferencia nélküliek arányát közel 0,1 , illetve 0,2 százalékponttal növeli. A hatás dinamikája azonban eltérő. A vízszintes időtengelyről leolvasható, hogy a Fidesz esetében az addicionális pozitív támogatottság csak egy hónapig tart, míg a preferencia nélküliek esetén lassabb, de négy hónapos növekedés figyelhető meg. Statisztikai értelemben egyik hatás sem tekinthető szignifikánsnak, mert mind az alsó, mind a felső hibahatár tartalmazza a nullát.

A tanulmányunk célja, hogy olyan impulzusválasz függvényeket becsüljünk, amelyekkel a korábban bemutatott kutatási kérdés statisztikailag tesztelhető.

A BVAR metodológia segítségével nyomon tudjuk követni, hogy az EU-s pénzek beáramlásának arányában, amit egyben a korrupció indikátorának is tekintünk, változik-e a választópolgárok politikai attitűdje, eltávolodnak-e a kormányzó politikai párttól, vagy változatlan marad a kormányzó párt támogatottsága. Ezen kérdések megválaszolásához a lehetséges impulzusválaszok következő aleseteit kell vizsgálni:

\subsubsection{A növekvő kihelyezett források meggyőzik a preferencia nélkülieket} a pozitív gazdasági változásokról és így emelkedik a kormánypártra szavazók aránya (pork and barrel).

1.2.1.1. aleset: Ebben az esetben az 1. ábrához hasonló impulzusválasz függvények között, a beáramló források impulzusára a politikai preferenciával nem rendelkezők arányának válasza szignifikánsan csökken (1. sor 3. oszlop IRF-függvény), míg a Fideszt támogatók arányának válasza szignifikánsan nő (1. sor 2. oszlop IRF-függvény).

1.2.1.2. aleset: Abban az esetben, ha a kormánypártot támogatók arányának válasza szignifikánsan növekszik, de a preferencia nélküliek változása statisztikailag nem csökken szignifikánsan, az új szavazóknak a szimpátia szavazata más pártoktól áramlik át a kormánypárt irányába.

1.2.1.3. aleset: Amennyiben egyik válasz sem szignifikáns, függetlenül az eltérés irányától, akkor a forrásbővülésnek nincs statisztikai értelemben vett közvetlenül kimutatható hatása a politikai preferenciák változására. Ennek egy lehetséges magyarázata, hogy a pork and barrel hatás ellensúlyozza a korrupció növekedését, ez azonban közvetlenül nem támasztható alá a modell segítségével. 


\section{TANULMÁNY}

\subsubsection{A növekvő kihelyezett források meggyőzik a kormánypárti szavazókat} a korrupció növekedéséröl és így csökken a Fidesz szavazók aránya a preferencia nélküliek növekedésével párhuzamosan (korrupció észlelés).

1.2.2.1. aleset: Ebben az esetben a források pozitív egységnyi sokkja miatt az impulzusválasz függvények között a kormánypártot választók arányának válaszfüggvényében szignifikáns csökkenés figyelhető meg, míg a preferencia nélküliek arányának válasza szignifikánsan nő. A változások a kiábrándulás jelenségére utalnak.

1.2.2.2. aleset: Ha a Fideszt támogatók arányának válaszfüggvénye a forrás sokk hatására szignifikánsan csökken, de a preferencia nélküliek arányának válasza nem szignifikánsan nő, akkor közvetetten kimutatjuk, hogy az általunk nem mért ellenzéki pártokhoz áramlottak át a szavazók.

1.2.2.3. aleset: Ha egyik változás sem szignifikáns, visszakapjuk az 1.2.1.3. alesetet, amely szerint nem tudunk statisztikai kapcsolatot kimutatni az idősorok között, vagy a hatás komplex természeténél fogva közvetlenül nem vizsgálható.

A potenciális kimeneteleket az 1. táblázat foglalja össze:

1. táblázat. Potenciális kimenetek az impulzusválasz függvények alapján

\begin{tabular}{|c|c|c|c|}
\hline Kimenetel & $\begin{array}{c}\Delta F I D \\
\text { (irány/szignifikancia) }\end{array}$ & $\begin{array}{c}\Delta N P \\
\text { (irány/szignifikancia) }\end{array}$ & Értelmezés \\
\hline 1.2.1.1. & + és szignifikáns & - és szignifikáns & $\begin{array}{l}\text { P\&B miatt átszavazás a Fi- } \\
\text { deszre a preferencia nélküli- } \\
\text { ekből }\end{array}$ \\
\hline 1.2.1.2. & + és szignifikáns & inszignifikáns & $\begin{array}{l}\text { P\&B miatt átszavazás a Fi- } \\
\text { deszre ellenzékből }\end{array}$ \\
\hline 1.2.1.3. & inszignifikáns & inszignifikáns & $\begin{array}{l}\text { A feltételezett statisztikai } \\
\text { kapcsolat nem létezik vagy } \\
\text { a P\&B hatása ellensúlyozza } \\
\text { korrupció növekedését }\end{array}$ \\
\hline 1.2.2.1. & - és szignifikáns & + és szignifikáns & $\begin{array}{l}\text { Korrupció észlelése és kiáb- } \\
\text { rándulás }\end{array}$ \\
\hline 1.2 .2 .2 & - és szignifikáns & inszignifikáns & $\begin{array}{l}\text { Kiábrándulás és átszavazás } \\
\text { másik pártra }\end{array}$ \\
\hline 1.2 .2 .3 & inszignifikáns & inszignifikáns & $\begin{array}{l}\text { A feltételezett statisztikai } \\
\text { kapcsolat nem létezik vagy } \\
\text { a P\&B hatása ellensúlyozza } \\
\text { korrupció növekedését }\end{array}$ \\
\hline
\end{tabular}

Forrás: Saját szerkesztés 


\section{TANULMÁNY}

Az 1. táblázatban nem tüntettük fel részletesen azokat a lehetséges aleseteket, amelyek empirikusan vagy a hipotézisünk alapján nem bírnak jelentőséggel. Például a felhasznált politikatudományi elméletek alapján nem értelmezhető, ha a beáramló források hatására mind a kormánypárt, mind a preferencia nélküliek aránya szignifikánsan nő, tehát az ellenzéki pártok szavazóinak egy része átszavaz a Fideszre, más része pedig kiábrándul saját pártjából és preferencia nélküli lesz (ezt támasztja alá a Fidesz és a preferencia nélküliek idősorainak kontraciklikus mozgása (lásd később a 3. ábrán). Mivel a források felett a kormányzópárt diszponál, így az ellenzéki pártokból való kiábrándulás nem feltétlenül indokolható meg. (Ez lényegében az 1.2.1.3. és 1.2.2.3. alesetek esetén vizsgálható közvetetten a pártpreferenciák IRF-jeiből.) A sokkhatásra történő negatív válaszok empirikusan nem meggyőzőek, mert egy ilyen hatáshoz a vizsgált időszakban az ellenzéki pártoknak jelentősen meg kellett volna erősödnie. Az érvényes alesetek alapján a következő tesztelhető hipotéziseket tudjuk felállítani.

\section{Hipotézis 1.: A kormányzati korrupció önálló tényezőként hat az állampol- gárok politikai attitúdjére.}

Ez azt feltételezi, hogy a kormányzati korrupció nagyságrendjének változása nyomán statisztikailag szignifikáns módon változik valamilyen irányban az állampolgárok politikai attitüdje.

Ezt nyomon követhető módon támasztják alá az ismertetett 1.2.1.1. és az 1.2.2.1. alesetek, illetve részben, de pontosan nem rekonstruálható módon az 1.2.1.2. és 1.2.2.2. potenciális kimenetek.

Hipotézis 2.: A kormányzati korrupció nem önálló tényező, hanem egy komplex percepció rendszer része, s ezért jelentősége jóval kisebb, mint amit számos kutató feltételez.

A második hipotézis azt feltételezi, hogy a kormányzati korrupció növekedésének vagy csökkenésének a hatása önmagában nem mérhető a választópolgárok politikai attitüdjére, mert a szavazók egy komplex hatásrendszer alapján alakítják ki politikai véleményüket, amiben a korrupció egy, s messze nem a legfontosabb hatóerö.

Ezt támasztják alá az 1.2.1.3. és az 1.2.2.3. alesetek, amelyek impulzusválaszaiban az EU-s támogatások hatása statisztikailag inszignifikáns a többi változóra, de az ellenzéki pártokból történő kiábrándulás irányából közvetetten feltételezhető a szignifikáns hatás. A második hipotézis tesztelésére a kormánypárt támogatóinak impulzusát kell vizsgálni a preferencia nélküliek válaszának arányára. 


\section{TANULMÁNY}

\section{Adatsorok és tulajdonságaik}

A következőkben bemutatjuk a felhasznált adatokat, azok forrását és a felhasználásuk mögött álló logikát. Az idősorok statisztikai modellezéséhez továbbá matematikai feltételeknek is teljesülniük kell, így stacionaritási vizsgálatot végzünk minden kiválasztott adatsoron.

\subsection{ADATSOROK BEMUTATÁSA}

\subsubsection{Európai uniós források beáramlása}

Az Európai Unió által 2010. 05. 01. és 2016. 02. 28. közötti 70 hónap során Magyarországnak nyújtott támogatások volumenét az Átlátszó.hu portálon elérhető pályázati támogatásokat aggregáló kimutatásból nyertük ${ }^{5}$, amely a hivatalos kormányzati statisztikákon alapul ${ }^{6}$.

A közel hat évet felölelő havi adatsort a Magyar Nemzeti Bank által számított fogyasztói árindexek segítségével, 2017. márciusi bázisra számítottuk át ${ }^{7}$. Havi gyakoriságú deflátor hiányában az új bázist nem a makrostatisztikákban megszokott módszertannal kalkuláltuk, de a CPI politikai szempontból még jobb választás is, mivel a fogyasztási cikkeken bekövetkező árváltozás a fogyasztók (azaz a szavazók) számára könnyebben érzékelhető.

A forintban megadott összegeket a modellezés során a Magyar Nemzeti Bank makrostatisztikák alapján havi középárfolyamon euróra váltottuk. Az átváltásra a későbbi modellezési fázisban volt szükség, mivel a százalékpontban mért népszerűségi mutatóktól való nagy volumenbeli eltérés az eredmények értelmezését jelentősen megnehezíti. Az idősor átlaga 424,37 millió euró, egy 23,03 és 2217,88 millió euró közötti intervallumon.

\footnotetext{
${ }^{5}$ Átlátszó.hu: https://adat.atlatszo.hu/eu-kereso/. Letöltés ideje: 2018. 05. 11.

${ }^{6}$ EU pályázati portál. Letöltés ideje: 2018. 05. 11.

${ }^{7}$ MNB CPI: https://www.mnb.hu/statisztika/statisztikai-adatok-informaciok/adatok-idosorok/i-fomakrogazdasagi-adatok. Letöltés ideje: 2018. 05. 11. A bázisidőszak az előtanulmány megírása idején került kiválasztásra. Mivel a becsléseken a bázisidőszak nem változtat, így a korábbi eredményeinket használtuk.
} 


\section{TANULMÁNY}

2. ábra. EU-s források beáramlása 2010 és 2016 között

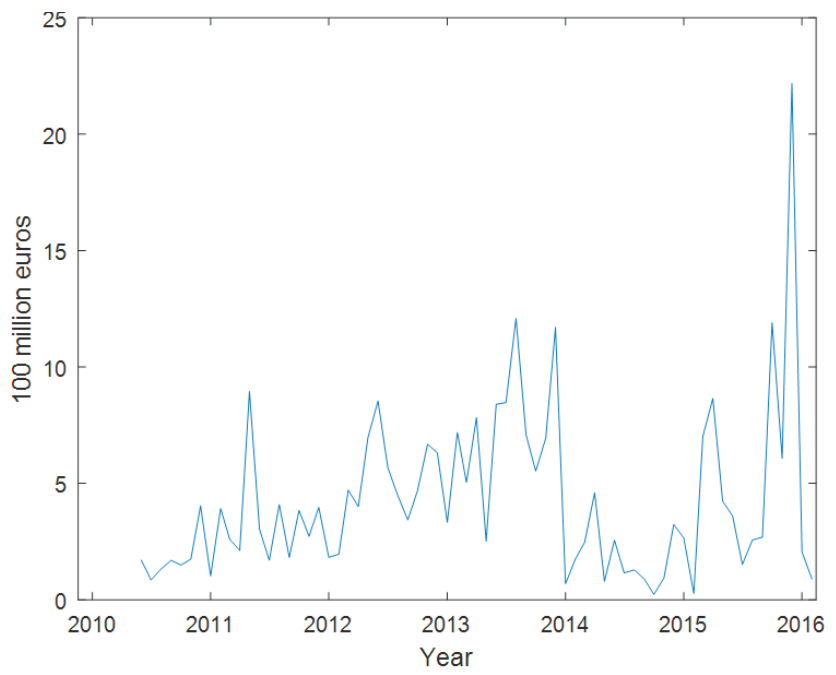

Forrás: Saját szerkesztés

A 2. ábrán látható idősorból látszik, hogy a kormányzó párt a 2014-es választások előtt folyamatosan növelte a források felhasználását. 2013 decemberében egy jelentős esést követően egészen márciusig ismét növekedtek a kifizetések. A csökkenés oka az Új Széchenyi Terv programozási időszakának 2013. végi zárása volt. Ezt követően 2014 januárjától egészen az áprilisi választásokat megelőző időszakig folyamatosan növekedtek a kifizetések, majd egészen 2014 novemberéig visszaesést láthatunk. Ezek alapján jól kimutatható a stratégiai célú forrásfelhasználás az EU-s támogatások idősorából.

\subsubsection{Közvéleménykutatások eredményei}

Az idősorelemzés elvégzéséhez megfelelő minőségű közvélemény-kutatási adatokra van szükség. Ebből az okból kifolyólag az eltérő közvélemény-kutató cégek által közölt méréseket mennyiségi és minőségi szempontok szerint értékeltük.

A felhasznált közvélemény-kutatások idősorai elérhetőek a kozvelemenykutatok. hu tematikus honlapról ${ }^{8}$. A kutatáshoz szükséges adatsorok az Ipsos/ZRI (88,57\%) és a Nézőpont Intézet (98,57\%) esetén a legnagyobb lefedettségűek a vizsgált időszakban. A többi intézet esetén sajnos olyan mértékű az adathiány, hogy az idősoros elemzés technikailag nem kivitelezhető.

${ }^{8}$ Forrás: http://kozvelemenykutatok.hu/. Letöltés ideje: 2017. 05. 18. 


\section{TANULMÁNY}

Adatminőség szempontjából, a megkérdezettek száma és a hibahatárok alapján vizsgáltuk a különböző intézeteket. Mindkét potenciális adatszolgáltató esetén személyes kérdőívek kitöltésével történik az adatfelvétel. Az Ipsos/ZRI CAPI (computer-assisted personal interviewing), azaz számítógéppel segített adatfelvételt végez, míg a Nézőpont Intézet TAPI (tablet-assisted personal interviewing), azaz táblagéppel segített kérdőívezéssel dolgozik. Mivel mindkét eljárás igényli a kérdezőbiztos személyes közreműködését, így minőség szempontjából azonosnak tekinthetjük az adatsorokat. A minta elemszáma alapján a Nézőpont Intézet kétszer akkora, 2000-es mintával dolgozik, ami a mintavételi hiba egy százalékponttal kisebb értékében is látható.

2. táblázat. Közvélemény-kutató intézetek metodológiája

\begin{tabular}{cccccc} 
& Ipsos/ZRI & Medián & Nézőpont & Századvég & Tárki \\
\hline \hline Adatfelvétel & Személyes & Személyes & Személyes & Telefonos & Személyes \\
módszere & (CAPI) & (CAPI) & (TAPI) & (CATI) & (CAPI) \\
Minta elemszáma & 1000 fó & 1200 fó & 2000 fó & 1000 fó & 1000 fó \\
Hibahatár & $\approx \pm 3,2 \%$ & $\approx \pm 2,9 \%$ & $\approx \pm 2,2 \%$ & $\approx \pm 3,2 \%$ & $\approx \pm 3,2 \%$ \\
\hline \hline
\end{tabular}

Forrás: Saját szerkesztés

Az eddigi minőségi kritériumokon túl empirikus benchmarkként használtuk a 2014-es országgyűlési választásokat. A választáson a Fidesz 45\%-os eredményt ért el, amihez a legközelebb a Tárki felmérése került 38\%-kal. A Nézőpont Intézet 37\%-ot mért, míg az Ipsos/ZRI több mint 13 százalékpontot tévedve, csupán 32\%ot prognosztizált. A relatíve nagy tévedések a korábbi közvélemény-kutatások során is jellemzőek voltak Magyarországon (Angelusz, 2002), így érdemes a felhasznált idősorokat úgy megközelíteni, mint a preferenciaváltozást mutató adatsorokat és nem mint pontos becsléseket.

Összegezve igaz, hogy a Nézőpont Intézet méréseivel összevetve a Tárki alacsonyabb mintából jobb becslést adott, azonban a vizsgált időszak adatainak csupán 77,14\%-át tartalmazza az idősora. Az Ipsos/ZRI pedig bár magas lefedettséggel rendelkezik, mérései pontatlanabbak a Nézőpont Intézet becsléseinél. Mivel a Nézőpont Intézet 2000 fős minta alapján, megközelítőleg $\pm 2,2 \%$-os hibahatár mellett mér, így az ő méréseiket használtuk fel az adatbázis elkészítése során. 
www. metszetek.unideb.hu

\section{TANULMÁNY}

3. ábra. Nagyobb pártok támogatottsága 2010 és 2016 között

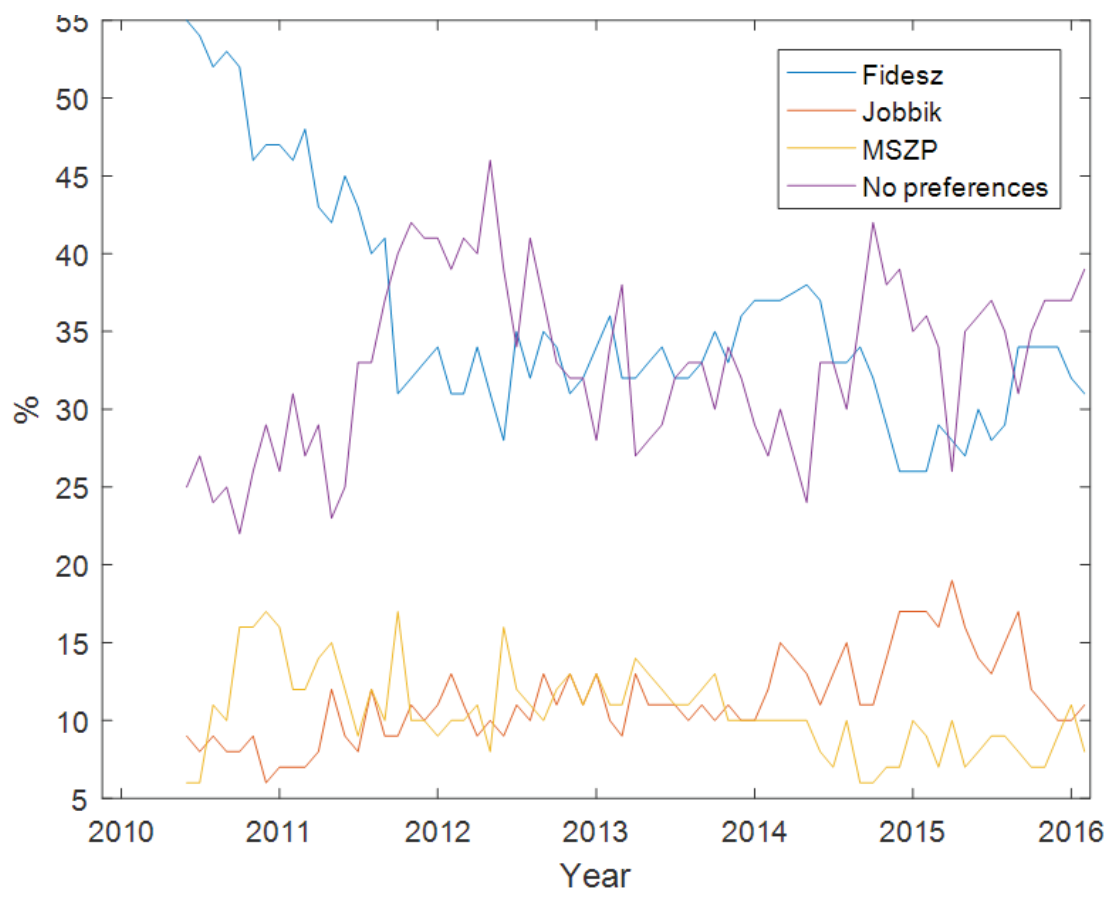

Forrás: Saját szerkesztés

A Nézőpont Intézet adataiból a kormányzópárt és a preferencia nélküliek idősorait használtuk fel, ahol az utóbbi kategóriába a bizonytalan és rejtőzködő szavazók is beleesnek. A 3. ábra alapján úgy gondoljuk, hogy a Fidesz támogatottságának változása kontraciklikus a preferencia nélküliek csoportjával szemben, így a többi nagyobb pártot nem érdemes bevenni a modellbe. Azaz a szemmel látható ellentétes mozgás miatt feltételezhetjük, hogy amennyiben valaki a korrupció miatt többé nem támogatja a kormányzópártot, az nagyobb valószínűséggel lesz preferencia nélküli, mint más párt támogatója.

A megfigyelések szűk keresztmetszetét az EU-s források adatainak elérhetősége képezi. A 2014-es választás hónapjában hiányzó adatpontokat lineáris interpolációval helyettesítettük, hogy minél kisebb mértékben változtassuk meg az adatsorok információtartalmát. A teljes adatbázis így három idősort és 70 havi megfigyelést tartalmaz a 2010. május és 2016. február közötti intervallumban. 


\section{TANULMÁNY}

\subsection{STACIONARITÁS VIZSGÁLATA}

Az idősoros becslések többsége - így a különböző VAR-modellek is - csak stacionárius adatsorokkal végezhetők el. Ezért minden idősorunk stacionaritását ADF-teszt segítségével ellenőriztük. (A teszt részletes ismertetése az A függelékben található.) A szükséges úgynevezett kovariancia stacionaritás azt jelenti, hogy az adott idősor átlaga és varianciája időben állandó, valamint az időben eltérő megfigyelések közötti kovariancia csak a késleltetés számától függ. Bármelyik feltétel megsértése nemstacioner idősorhoz vezet. A nemstacioner idősorok pedig nem rendelkeznek hoszszútávú egyensúllyal, amihez egy temporális sokk után az idősor visszatérhetne.

Az ADF-tesztek előtt gyakran futtatnak úgynevezett információs kritériumon alapuló specifikációs teszteket. Ezek célja, hogy az eltérő késleltetésszámú modellek közül kiválasszák azokat, amelyek egyszerre illeszkednek jól és tartalmazzák a lehető legkevesebb paramétert. Ettől eltekintettünk, mivel a VAR-rendszerek jellemzően túlparaméterezettek és nagy késleltetésszám mellett a modellünk nehezen becsülhetővé vált volna. Így a csak kettő vagy annál kevesebb késleltetésszámú modelleket ellenőriztük egyesével.

A változókon nullától kettő késleltetésig, két eltérő típusú modellt és azokon ADF-tesztet futtattunk. Egyet kizárólag késleltetésekkel, egyet pedig trenddel és késleltetésekkel. A trendspecifikáció esetén feltételezzük, hogy az uniós támogatásokban lehet lokális növekedés, amit a teszt kimutathat, továbbá azt, hogy a kormánypárt támogatottsága csökkenő trendet követ.

Ezen felül az első differenciált változókon is lefuttattuk a késleltetésekkel ellátott ADF-tesztet, mivel egységgyök folyamat esetén a differenciálás eltávolíthat egy esetleges sztochasztikus trendet is. A 27 lefuttatott teszt eredményei a 3. táblázatban találhatóak. 
www. metszetek.unideb.hu

\section{TANULMÁNY}

3. táblázat. ADF-tesztek eredményei eltérő specifikációk mellett

\begin{tabular}{cccccc} 
Változó & Késleltetés & Trend & p-érték & t-statisztika & Krit. érték \\
\hline \hline FUNDS & 0 & $\mathrm{X}$ & 0.0010 & -3.5532 & -1.9451 \\
FID & 0 & $\mathrm{X}$ & 0.1701 & -1.3233 & -1.9451 \\
NP & 0 & $\mathrm{X}$ & 0.5874 & -0.1659 & -1.9451 \\
\hline FUNDS & 1 & $\mathrm{X}$ & 0.0377 & -2.0705 & -1.9451 \\
FID & 1 & $\mathrm{X}$ & 0.0688 & -1.7974 & -1.9452 \\
NP & 1 & $\mathrm{X}$ & 0.6866 & 0.1056 & -1.9452 \\
\hline FUNDS & 2 & $\mathrm{X}$ & 0.0937 & -1.6462 & -1.9452 \\
FID & 2 & $\mathrm{X}$ & 0.0414 & -2.0291 & -1.9452 \\
NP & 2 & $\mathrm{X}$ & 0.7531 & 0.2875 & -1.9452 \\
\hline FUNDS & 0 & $\checkmark$ & 0.0010 & -6.4439 & -3.4783 \\
FID & 0 & $\checkmark$ & 0.4420 & -2.3021 & -3.4783 \\
NP & 0 & $\checkmark$ & 0.0681 & -3.3441 & -3.4783 \\
\hline FUNDS & 1 & $\checkmark$ & 0.0127 & -4.0239 & -3.4795 \\
FID & 1 & $\checkmark$ & 0.4586 & -2.2676 & -3.4795 \\
NP & 1 & $\checkmark$ & 0.2326 & -2.7393 & -3.4795 \\
\hline FUNDS & 2 & $\checkmark$ & 0.0249 & -3.7655 & -3.4808 \\
FID & 2 & $\checkmark$ & 0.5664 & -2.0423 & -3.4808 \\
NP & 2 & $\checkmark$ & 0.5405 & -2.0964 & -3.4808 \\
\hline$\Delta$ FUNDS & 0 & $\mathrm{X}$ & 0.001 & -14.3004 & -1.9452 \\
$\Delta$ FID & 0 & $\mathrm{X}$ & 0.001 & -10.0902 & -1.9452 \\
$\Delta$ NP & 0 & $\mathrm{X}$ & 0.001 & -10.6469 & -1.9452 \\
\hline$\Delta$ FUNDS & 1 & $\mathrm{X}$ & 0.001 & -6.8975 & -1.9452 \\
$\Delta$ FID & 1 & $\mathrm{X}$ & 0.001 & -7.4949 & -1.9452 \\
$\Delta$ NP & 1 & $\mathrm{X}$ & 0.001 & -8.4607 & -1.9452 \\
\hline$\Delta$ FUNDS & 2 & $\mathrm{X}$ & 0.001 & -6.5964 & -1.9453 \\
$\Delta$ FID & 2 & $\mathrm{X}$ & 0.001 & -4.5476 & -1.9453 \\
$\Delta$ NP & 2 & $\mathrm{X}$ & 0.001 & -5.5713 & -1.9453 \\
\hline \hline
\end{tabular}

Forrás: Saját szerkesztés

A tesztek nullhipotézise, hogy az idősor nem stacioner, azaz egységgyök folyamat. A modellezés szempontjából ennek elutasításában vagyunk érdekeltek. Differenciálatlan változók használata esetén, az EU-s források nulla és egy késleltetés mellett, illetve bármely trendet tartalmazó modell esetén 5\%-os szignifikanciaszinten stacioner folyamatok. A kormánypárt változója kizárólag két késleltetést tartalmazó modellek esetén stacioner, valamint minden trendet tartalmazó modellben megfigyelhető egységgyök folyamat. A preferencia nélküliek idősora minden differenciálatlan verzióban egységgyököt tartalmaznak. A differenciált idősorok esetében bármely késleltetésszám mellett 1\%-os szignifikanciaszinten el tudtuk utasítani a nullhipotézist. 


\section{TANULMÁNY}

A tesztek alapján minden becslés során a felhasznált változók első differenciáját használtuk. Így jelöli az EU-ból származó források első differenciáját. A idősor jelöli a kormánypártot preferálók részarányának hónapról hónapra történő változását a mintában. A változó pedig a preferenciával nem rendelkező vagy bizonytalan, esetleg rejtőzködő szavazók arányának változását jelenti.

\section{Modellspecifikáció és eredmények}

A következőkben ismertetjük az alkalmazott három becslési eljárást és eredményeiket, majd eltérő szempontok mentén rangsoroljuk felhasználhatóságukat. (A részletes levezetéseket a $B$ függelékben mutatjuk be.)

\subsection{MODELLSPECIFIKÁCIÓ}

\subsubsection{A BVAR-modellek felépítése}

A vektor autoregressziók többegyenletes lineáris regressziók. Minden a modellben szereplő változó egy-egy külön egyenlettel rendelkezik, melyekben saját és az összes egyéb változó késleltetett értékei szerepelnek mint magyarázó változók.

Az ilyen típusú kiinduló modellt redukált modellnek nevezzük. A redukált modellben a magyarázó változók mind endogének és így nem lehet ceteris paribus értelmezést adni a becsült koefficienseknek. A modellt így transzformációk segítségével át kell alakítani olyan alakra, ahol a változók egymásra hatását a politikatudományi szakirodalom alapján előre meghatározzuk. Ez az identifikációs lépés eredményezi a strukturális modellt.

A strukturális modellünkben a hatásirányok a következőek: úgy gondoljuk, hogy az EU-s források változása befolyásolja a kormánypárt támogatottságának és a preferencia nélküliek változását, de fordított irányú kapcsolat nem létezik. Tehát a két politikai idősor változásának nincs hatása az EU-s források kihelyezésére. Ezen felül megengedjük, hogy a kormánypárt támogatottságának változását érő sokk hasson a preferencia nélküliek arányának változására.

A redukált modellünkben minden egyenletben három időszaki késleltetést alkalmaztunk. A megbecsülendő paraméterek száma így 39. (Egyenletenként $3 \times 3$ együttható paraméter és egy konstans, valamint a 3 egyenletre együtt egy $3 \times 3$-as variancia-kovariancia mátrix.) Mivel a differenciálás után csak 69 adatpontunk maradt, így a paraméterbecslések statisztikai szignifikanciájának megállapításakor a t-statisztikáink szabadságfoka mindössze 30. Ez nem elegendő ahhoz, hogy az OLS becslés aszimptotikus tulajdonságai érvényesüljenek, így a paraméterbecsléseket bayes-i Monte Carlo-szimulációk segítségével állítjuk elő. 


\section{TANULMÁNY}

\subsubsection{A bayes-i keret jelentősége}

A hagyományos frekventista és a bayes-i modellezés közötti különbség a következőképpen foglalható össze. A frekventista elmélet szerint a mintavétel során nyert adatokat egy $\theta$ sokasági paraméter határozza meg, így annak valószínűsége, hogy egy adatpont egy tapasztalt értéket vesz fel $P(x \mid \theta)$. Tehát a paraméter fix és a mintavétel során kapott érték ennek függvénye. Így egy $n$ elemű minta esetén felírható a likelihood függvény a kapott adatok együttes eloszlásával.

A bayes-i modellezés ezzel szemben magát a sokasági paramétert is valószínűségi változóként kezeli és az úgynevezett a posteriori eloszlás a likelihood és a prior szorzatával arányos a következőképp: $P(\theta \mid x) \propto P(\theta) P(x \mid \theta)$. Így a paraméterbecslés során nemcsak a likelihood, hanem a prior értéke is befolyásolja a kapott eredményt.

A priorok lehetnek analitikusak, de szimuláció során numerikusan előállított értékek is. A modellezés során az a szerepük, hogy az adathiányból származó hiányos információt pótolják. Közös tulajdonságuk, hogy növekvő mintaelemszám esetén súlyuk folyamatosan csökken és ha $n \rightarrow \infty$ a bayes-i becslés konvergál a hagyományos frekventista becslés eredményéhez. A bayes-i modellek ezért alkalmasak a kis mintaelemszám korrigálására. Az elemzések elvégzése során három eltérő eljárást használtunk: 1) analitikus Minnesota-priort, 2) analitikus konjugált normális - Wishart priort és 3) független prior - poszterior priort. A modellek között RMSE-kritérium alapján döntöttünk. ${ }^{9}$

\subsubsection{A VAR-modellek reprezentációja impulzusválasz függvények segítségével}

A becsült BVAR-modellek túlparaméterezettek, azaz a becsült együtthatók magas száma miatt a hagyományos módon nem interpretálhatóak. Az elkészült becsléseket így grafikus úton mutatjuk be impulzusválasz függvények segítségével. Az IRF-ek egy adott változó maradéktagjában bekövetkező egy egységnyi sokk hatását mutatják meg a többi endogén változóra a vektor autoregresszióban.

Az IRF-ek előállításának lényege, hogy minden autoregresszív folyamat felbontható úgynevezett mozgóátlagok sorösszegére. Ez azt jelenti, hogy a vektorautoregresszió egyenletei külön-külön felbonthatóak a maradéktagokban található hibák összegére. Az IRF így egy ábrán képes a két változó közötti dinamikus kapcsolat reprezentálására. Az ábráról leolvasható az impulzus változót érő egységnyi sokk hatása a választ adó változóra, illetve megállapítható róla, hogy a hatás hány időszakig szignifikáns statisztikailag.

${ }^{9}$ Az RMSE (Root Mean Squared Error) mutatószám a megfigyelések maradéktagjait négyzetre emeli, majd átlagukból gyököt von. A négyzetre emelés miatt a pozitív és negatív hibák volumene azonos mértékben kerül beszámításra az előjelüktől függetlenül. A gyökvonás pedig semlegesíti a nagyobb hibák felerősített hatását a pontossági mutatószámra. 


\section{TANULMÁNY}

\subsection{EREDMÉNYEK}

\subsubsection{Bayes-i VAR-modellek illesztése}

A differenciálás utáni 69 adatpontra három eltérő bayes-i VAR-modellt illesztettünk és a priorok generálásához az ismertetett eljárásokat használtuk. A modelleket húsz megfigyelés után levágtuk és expanding window eljárással intervallumon belül becsülve, átlagos négyzetes gyökeltérést (RMSE) és torzítás-variancia felbontása alapján összehasonlíthatóvá tettük a modelleket.

4. táblázat. Eljárások és pontbecsléseik összehasonlítása

\begin{tabular}{cccc} 
Modell & \multicolumn{3}{c}{ Analitikus Minnesota } \\
\hline \hline Változó & $\Delta F U N D S$ & $\Delta F I D$ & $\Delta N P$ \\
\hline RMSE & 6,92 & 3,59 & 6,18 \\
Torzítás (\%) & 0,82 & 0,4 & 0,52 \\
Variancia (\%) & 0,18 & 0,6 & 0,48 \\
\hline Átlag & $-8,58$ & $-0,46$ & 0,53 \\
Szórás & 4,56 & 3,35 & 5,22 \\
\hline \hline
\end{tabular}

\begin{tabular}{cccc} 
Modell & \multicolumn{3}{c}{ AK normális - Wishart } \\
\hline \hline Változó & $\Delta F U N D S$ & $\Delta F I D$ & $\Delta N P$ \\
\hline RMSE & 6,69 & 3,52 & 6,25 \\
Torzítás (\%) & 0,85 & 0,44 & 0,57 \\
Variancia (\%) & 0,15 & 0,56 & 0,43 \\
\hline Átlag & $-10,16$ & 0,14 & 1,68 \\
Szórás & 4,88 & 3,63 & 5,53 \\
\hline \hline
\end{tabular}

\begin{tabular}{cccc} 
Modell & \multicolumn{3}{c}{ Független prior-poszterior } \\
\hline \hline Változó & $\Delta F U N D S$ & $\Delta F I D$ & $\Delta N P$ \\
\hline RMSE & 6,87 & 3,55 & 6,16 \\
Torzítás (\%) & 0,83 & 0,35 & 0,52 \\
Variancia (\%) & 0,17 & 0,65 & 0,48 \\
\hline Átlag & $-8,03$ & 0,23 & 0,63 \\
Szórás & 4,78 & 3,63 & 5,22 \\
\hline \hline
\end{tabular}

Forrás: Saját szerkesztés

Az RMSE alapján az analitikus konjugált normális - Wishart priort érdemes használni az EU-s források és a Fideszt preferálók változásának előrejelzése esetén, míg független prior-poszteriort a preferencia nélküliek változásakor. A torzítás-variancia felbontás az RMSE értékekhez hasonlóan nem mutat különösebb eltérést a becsült modellek között. A 4. táblázat tartalmazza az eltérő eljárások pontbecsléseit. A 


\section{TANULMÁNY}

szórások minden változó esetén hasonló nagyságrendűek, de a poszteriori várható értékekben jelentős eltéréseket tapasztalhatunk. (A becsült prediktív sűrűségek megtalálhatóak a $C$ függelékben.) Az eltérés miatt úgy döntöttünk, hogy az összes becslés IRF-ét bemutatjuk.

\subsubsection{Impulzusválasz függvények}

Mivel elsősorban a kormánypárt és a preferencia nélküliek változásának válaszfüggvénye lényeges az EU-s támogatás sokkja esetén, így az ezeket a változókat a legjobban kezelő priort, az analitikus konjugált normális - Wishart priort ismertetjük elsőként. Az eltérő technikával becsült impulzusválaszok azonban nagyon hasonlítanak, így a modellből levonható következtetéseket nem változtatja meg a két másik modell elhagyása. A teljes impulzusválasz kimutatások megtalálhatóak a $C$ függelékben, a főszövegben csak a kutatás szempontjából lényeges IRF-ek vizsgálatára fókuszálunk.

\section{4. ábra. Impulzusválasz függvények analitikus konjugált} normál-Wishart prior alkalmazásával
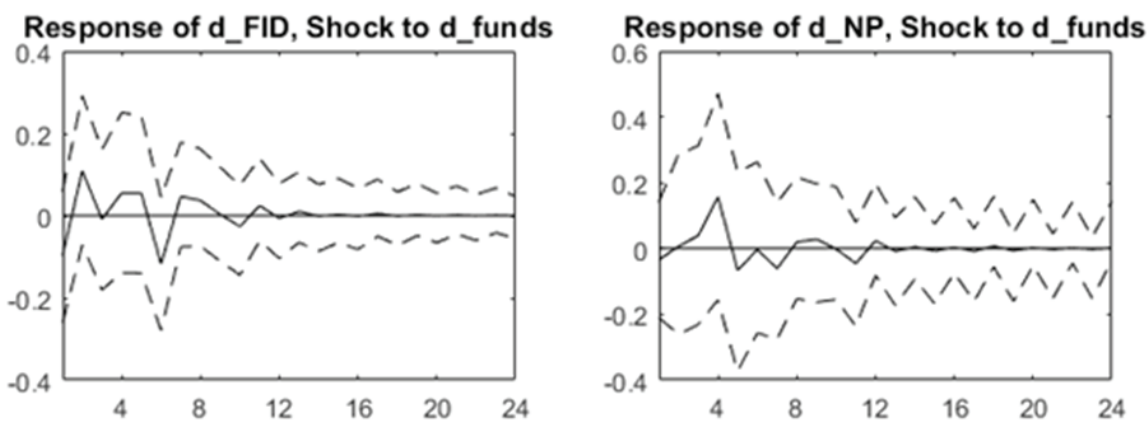

Forrás: Saját szerkesztés 


\section{TANULMÁNY}

5. ábra. Impulzusválasz függvények analitikus Minnesota-prior alkalmazásával

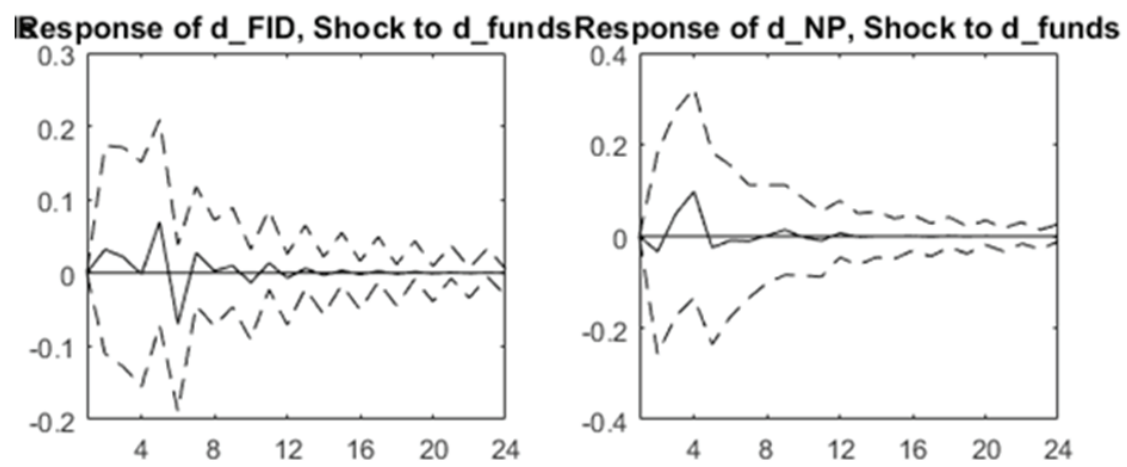

Forrás: Saját szerkesztés

6. ábra. Impulzusválasz függvények független prior-posterior becslés alkalmazásával
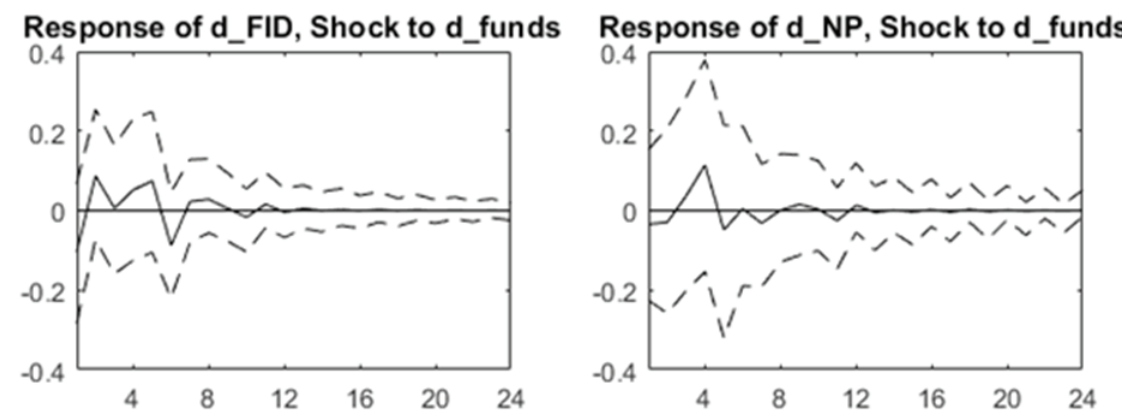

Forrás: Saját szerkesztés

A 4-6. ábrák impulzusválasz függvényei alapján sem a $\triangle F I D$, sem a $\triangle N P$ változók válaszai nem különböznek statisztikailag szignifikánsan nullától a $\triangle F U N D S$ változó egységnyi impulzusát követően. Másképp fogalmazva a becsült időszaki IRF hibahatárait jelző szaggatott vonalon belül megtalálható a nulla érték, így 10\%-os szignifikanciaszinten nem tudjuk elutasítani a nullhipotézist, miszerint a hatás nem nulla.

Pusztán a becsült értékeket vizsgálva a preferencia nélküliek növekedése minden esetben kis esés után négy hónapig növekszik 0,1-től 0,18 százalékpont körüli értékig. A kormánypárt támogatásának változása volumenét tekintve viszont lényegesen heterogénebb. A kivehető hasonlóság, hogy minden esetben egy kezdeti növekedést csökkenés, majd újabb növekedés és csökkenés követ. 


\section{TANULMÁNY}

Az eredmények alapján elmondhatjuk, hogy az EU-s források nem befolyásolják statisztikailag szignifikánsan a kormányzó párt népszerűségét. Az IRF-ek a bevezetésben tárgyalt 1.2.1.3. és 1.2.2.3. aleseteket támasztják alá, így az első hipotézisünket megcáfoltuk. Nem mutatható ki közvetlen hatás a beáramló EU-s források és a politikai preferenciák között. Felvetődhet a kérdés, hogy az alkalmazott BVAR módszer egyáltalán képes-e kimutatni bármilyen változást a felhasznált idősorok között? Ebben az esetben ugyanis a második hipotézis megválaszolása is árnyaltabb.

7. ábra. Impulzusválasz függvények a politikai idősorok közötti kapcsolat kimutatására analitikus Minnesota-prior alkalmazása esetén

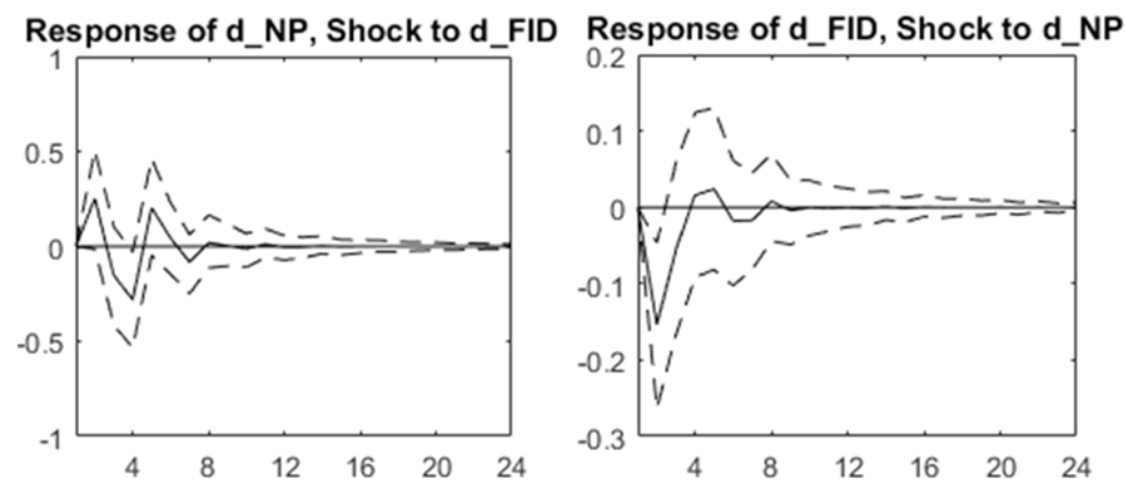

Forrás: Saját szerkesztés

Ennek tesztelésére a politikai preferenciák közötti hatásokat vizsgáltuk meg analitikus Minnesota-prior alkalmazása esetén a 7. ábrán. ${ }^{10} \mathrm{~A}$ Fidesz támogatottságának változásában bekövetkező egy százalékpontos növekedés hatására, a preferencia nélküliek támogatottságának változása megközelítőleg 0,25 százalékpontot nő, amit feltehetően az elemzésben nem szerepeltetett pártok támogatóinak csökkenése eredményez. Azaz minél többen támogatják a kormánypártot, annál többen ábrándulnak ki az ellenzékből. Ez a hatás körülbelül egy hónapig jelent nullától eltérő statisztikailag szignifikánsan kimutatható eltérést az egyensúlyi szinttől.

Logikailag hasonló eredményeket ad a fordított eset, amikor a preferencia nélküliek változásának egy százalékpontos sokkja 10\%-os szignifikanciaszinten megközelítőleg 0,13 százalékponttal csökkenti a kormánypárt szavazóinak változását. Ez a hatás szintén körülbelül egy hónapig szignifikáns, majd visszatér az egyensúlyi

${ }^{10}$ A választás oka, hogy a 7. táblázat alapján az analitikus Minnesota-prior rendelkezik a második legkisebb torzítással a kormánypárt idősora esetén és a független prior-poszterior eljárással megegyező minimális torzítása van a preferencia nélküliek változásában. A többi prior is hasonló, bár nem ilyen egyértelmű eredményeket ad. 


\section{TANULMÁNY}

szinthez. A tapasztalt jelenségekre úgy fordíthatjuk le az eredményt, hogy az általános kiábrándulás jellemzően az elemzésben nem szereplő ellenzéki pártok között jelentős.

Az eredményeket a második hipotézis vizsgálatára is felhasználhatjuk. Tegyük fel, hogy az EU-s források hatása kettős és a szavazók egy részénél a növekedési sokk a kormánypártra történő átszavazást, míg egy másik részüknél kiábrándulást okoz. Ezt a két ellentétes hatást az idősor egyszerre tartalmazza, így a modellben ellensúlyozhatják egymást, így eredményezve a tapasztalt inszignifikáns kimenetelt.

Ha feltesszük, hogy a szavazók eltérő témák iránti preferenciája politikai állásuktól függően többé-kevésbé homogén, akkor maga a 7. ábra bal panelje az identifikáció miatt közvetetten alkalmas a korrupció más témákhoz mért jelentőségének vizsgálatára is.

A kormánypárt támogatottságát önkényesen 1 százalékponttal növeltük, melyre válaszul a preferencia nélküliek arányának növekedése statisztikailag szignifikánsan 0,25 százalékponttal nőtt a sokkot követő egy hónapban. Ennek a hatásnak elméletben az ellenzéki pártok 1,25 százalékpontos csökkenésével kellene együtt járnia. Ezt arányosítva, ha a preferenciák legalább bizonyos mértékben homogének, akkor az ellenzékből kiábrándulók 80\%-a nem lesz preferencia nélküli, hanem inkább átszavaz a kormánypártra. Mivel ebből a hatásból az identifikáción keresztül már kiszűrtük a beáramló források hatását (lásd $B$ függelék 17. egyenlet), így kijelenthetjük, hogy a preferenciák változásának nagy része nem a korrupciótól függ, hanem egyéb, a modellben nem vizsgált tényezőktől.

Az impulzusválaszok eredményei alapján végül elvetettük a első hipotézist, miszerint az európai uniós források mint korrupció proxy hatnak a kormányzópárt támogatottságára. Úgy tűnik, hogy maga a korrupció nem befolyásolja a politikai preferenciák változását olyan mértékben, mint amit a szakirodalom egy jelentős része feltételez.

\section{Konklúzió}

A tanulmány azt a célt tűzte ki, hogy állást foglaljon a korrupció politikai hatását vizsgáló irodalom vitájában. A tanulmányban egy a politikatudományban eddig nem alkalmazott elemzési módszert választottunk ki arra, hogy nyomon kövessük a korrupció mértékének hatását a választópolgárok politikai attitűdjének alakulására.

A bayes-i vektor autoregresszió eredményei nem szolgáltatnak bizonyítékot az első hipotézisünkre. Vagyis a kormányzati korrupció arányának változása nem hat önálló tényezőként az állampolgárok politikai attitűdjére. (A korrupció proxyként használt EU-s források nagyságrendjének változása nyomán nem változik az állampolgárok politikai attitűdje statisztikailag szignifikáns módon.) 


\section{TANULMÁNY}

A kutatási eredményeink a második hipotézist támasztják alá, miszerint a kormányzati korrupció mértékének változása nem önálló tényező az állampolgárok politikai választásának alakulásában, hanem egy komplex percepciórendszer része, s ezért jelentősége jóval kisebb, mint amit számos kutató feltételez. A kormányzati korrupció növekedésének vagy csökkenésének a hatása önmagában nem mérhető a választópolgárok politikai attitűdjére, mert a szavazók egy komplex hatásrendszer alapján alakítják ki politikai véleményüket, amiben a korrupció egy, és messze nem a legfontosabb hatóerő.

További kutatást igényel annak vizsgálata, hogy ez a jelenség vajon speciálisan Magyarországra jellemző, mivel a magyar politikai rendszer sajátosságai megakadályozzák a korrupció észlelésének átkonvertálódását politikai szavazattá, vagy más országokra is érvényes megállapítás. A magyar politikai rendszer számos sajátossága egybeesik azokkal a tényezőkkel, amelyeket az 1.1. fejezet irodalomáttekintése azonosított mint intézményi gátló tényezőket. A nemzetközi irodalom által feltárt jelenségek közül különösen érvényesek lehetnek Magyarországra az alábbiak: poszt-káosz (poszt-válság) helyzet, a választójogi rendszer beépített korlátjai, a tény, miszerint a sajtó és a médiák többsége kormánypárti, az ellenzék számos pártjának korrupciós érintettsége, a patrónus-kliens beágyazottság kialakulása és végül, de nem utolsósorban az a tény, hogy az EU-forrásokból megvalósuló beruházásoknak pozitív a hatása az állampolgárok nagy részére, így a gazdaság és az életszínvonal növekedése miatt szemet hunynak a kormányon levők korrupciója felett.

\section{Irodalom}

Angelusz R. (2002): Közvéleménykutatások és a pluralizmus ignoranciája. Budapest, Médiakutató.

Balázs J. (1991): Democracy Post-State Socialist Style. Eastern Europe in Transition. A Chance or Threat to Peace. Polish Institute of International Affairs. Warsaw. 1991: 82-89.

Balázs J. (2002): A bűnözéstől a szervezett bűnözésig. Gazdaság és Társadalom 2002(2): 177-207.

Banerjee, A. - Green, D. P. - McManus, J. - Pande, R. (2014): Are poor voters indifferent to whether elected leaders are criminal or corrupt? A vignette experiment in rural India. Political Communication 31(3): 391-407. doi: 10.1080/10584609.2014.914615

Beck, L. M. S. (1988): Economics and Elections. The Major Western Democracies. Ann Arbor, University of Michigan Press. 


\section{TANULMÁNY}

Beck, L. M. S. - Stegmaier, M. (2000): Economic determinants of electoral outcomes. Annual Review of Political Science (3): 183-219. doi: https://doi.org/10.1146/ annurev.polisci.3.1.183

Box-Steffensmeier, J. - Freeman, J. - Hitt, M. (2014): Time Series Analysis for the Social Sciences. New York, Cambridge University Press.

Bull, M. J. - Newell, J. L. (1997): New avenues in the study of political corruption. Crime, Law and Social Change, 27 (3-4): 169-83. doi:10.1023/A:1008232802273

Chang, E. C. C. - Kerr, N. N. (2009): Do voters have different attitudes toward corruption? The sources and implications of popular perceptions and tolerance of political corruption. Afrobarometer Working Papers. No. 116.

Chang, E. C.C. - Golden, M. A. - Hill, S. J. (2010): Legislative Malfeasance and Political Accountability. Word Politics 62 (2): 177-220. doi: 10.1017/s0043887110000031.

Charon, N. (2011): Party Systems, Electoral Systems and Constraints on Corruption. Electoral Studies, 30(4): 595-606. doi: 10.1016/j.electstud.2011.05.003

Civilhetes (2016): Mivel nincs korrupció, 20\% a drágulás Paksnál! https://civilhetes.net/mivel-nincs-korrupcio-20-a-dragulas-paksnal (utolsó letöltés ideje: 2020. 09. 30.)

Civitas Intézet (2018): Fekete könyv. Korrupció Magyarországon 2010-2018 között. Civitas Intézet Gazdasági és Társadalomtudományi Kutató Zrt. és Transparency International Magyarország Alapítvány.

Della Porta, D. - Vannucci, A. (1997): The resources of corruption: some reflections from the Italian case. Crime, Law and Social Change, 27 (3-4): 231-54. doi: 10.1080/13532940500284192

Ecker, A. - Glinitzer, K. - Meyer, T. M. (2016): Corruption performance voting and the electoral context. European Political Science Review. 8 (3): 333-354. doi: $10.1017 /$ S1755773915000053.

Enders, W. (1995): Applied econometric time series. New York, Wiley.

Európai Bizottság (2015): 2015. évi országjelentés - Magyarország a makrogazdasági egyensúlyhiányok megelőzéséről és kiigazításáról szóló részletes vizsgálattal. SWD/2015/0036 final https://eur-lex.europa.eu/legal-content/HU/TXT/?uri=CELEX\%3A52015SC0036 (utolsó letöltés ideje: 2020. 09. 30.)

Fábián Z. - Závecz T. - Páthy-Dencső B. (2010): A pártok népszerűségének változása Magyarországon, 1990-2010. Társadalmi Riport: Tárki: 491-511.

Ferraz, C. - Finan, F. (2008): Exposing Corrupt Politicians: The Effects of Brazil's Publicly Released Audits on Electoral Outcomes. Quarterly Journal of Economics, 123(2):703-745 doi: https://doi.org/10.1162/qjec.2008.123.2.703. 


\section{TANULMÁNY}

Fenyvesi É. (2014): A korrupció mérhetősége. Multidiszciplináris kihívások - sokszínű válaszok. Budapesti Gazdasági Főiskola Kereskedelmi, Vendéglátóipari és Idegenforgalmi Kar, Budapest, 21-33.

Fernández-Vázquez, P. - Barberá, P. - Rivero, G. (2016): Rooting out corruption or rooting for corruption? The heterogeneous electoral consequences of scandals. Political Science Research and Methods 4(2): 379-397. doi: 10.1017/psrm.2015.8.

Gingerich, D. W. (2009): Corruption and political decay: Evidence from Bolivia. Quarterly Journal of Political Science 4(1): 1-34. doi: 10.1561/100.00008003.

Golden, M. A. (2010): Puzzles of political corruption in modern advanced democracies. In: Magara, H. (ed.): Democracy and Accountability: Globalized Political Responsibility. Tokyo, Fukosha.

Golden, M. A. - Mahdavi, P. (2015): The institutional components of political corruption. In: Gandhi, J. - Ruiz-Rufino, R. (eds.): Routledge Handbook of Comparative Political Institutions. New York, Routledge Press.

Hazama, Y. (2017): Economic and corruption voting in a predominant party system: The case of Turkey. Acta Politika, 2017 (February). doi: .10.1057/s41269-0170041-5.

Heidenheimer, A. (2002): Perspectives on the Perception of Corruption. In: Heidenheimer, A. - Michael, J. (eds.): Political Corruption: Concepts and Contexts. New Brunswick, NJ, Transaction Publishers.

Innes, A. (2014): The Political Economy of State Capture in Central Europe. Journal of Common Market Studies 2014(1): 88-104. doi: 10.1111/jcms.12079.

Jancsics D. - Jávor I. (2012): Corrupt Governmental Networks. International Public Management Journal 2012(1): 62-99. doi: https://doi.org/10.1080/10967494. 2012.684019.

Keller T. (2014): Megfogyva bár, de törve... Mérsékelten javuló mutatók, súlyosan növekvő politikai polarizáltság a magyar értékrendszerben, változások 2009 és 2013 között. In: Tóth I. Gy. - Kolosi T. (szerk.): Társadalmi riport 2014. Budapest, Tárki.

Kirschgassner, G. - Wolters, J. (2013): Introduction to Modern Time Series Analysis. Berlin, Springer Texts in Business and Economics.

Klašnja, M. - Tucker, J. A. (2013): The economy, corruption, and the vote: Evidence from experiments in Sweden and Moldova. Electoral Studies (32): 536-543. doi: 10.1016/j.electstud.2013.05.007.

Koop, G. - Korobilis, D. (2010): Bayesian Multivariate Time Series Methods for Empirical Macroeconomics. Glasgow, University of Strathclyde. 


\section{TANULMÁNY}

Krause, S. - Méndez, F. (2009): Corruption and Elections: An Empirical Study for a Cross-Section of Countries. Economics and Politics, 21(2): 179-200. doi: 10.1111/j.1468-0343.2008.00341.x.

Kurer, O. (2005): Corruption: An Alternative Approach to Its Definition and Measurement. Political Studies (53): 222-239. doi: 10.1111/j.1467-9248.2005. 00525.x.

Lengyel L. (1998): Esszé a politikai korrupcióról. In: Gombár Cs. - Hankiss E. - Lengyel L. (szerk.): Irások a korrupcioról. Korridor, Budapest.

Lewis-Beck, M. S. - Stegmaier, M. (2013): The VP-Function Revisited: A Survey of the Literature on Vote and Popularity Functions after over 40 Years. Public Choice 157(3-4): 367-385. doi: 10.1007/s11127-013-0086-6.

Ligeti M. (2019): Korrupció. In: Martin J. - Nagy G. - Ligeti M. (szerk.): Korrupció Magyarországon 2010-2018. Civitas, Budapest.

Linde, J. - Erlingsson, G, (2013): The Eroding Effect of Corruption on System Support in Sweden Governance: An International Journal of Policy. Administration, and Institutions, 26(3) 585-603. doi: 10.1111/gove.12004.

Magone, J. (2003): Political Corruption in Portugal. In: Bull, M. - Newell, N. (eds.): Corruption in Contemporary Politics. Palgrave, Basingstoke, 120-133.

Magyar B. (szerk.) (2013): Magyar Polip. A posztkommunista maffiaállam. Budapest, Noran Libro.

Manzetti, L. - Wilson, C. J. (2007): Why do corrupt governments maintain public support? Comparative Political Studies 40(8): 949-970. doi: 10.1177/ 0010414005285759.

Mungiu-Pippidi, A. (2006): Corruption: Diagnosis and Treatment. Journal of Democracy 17 (3): 86-99.

Napi.hu (2018): Odacsap az EU: újra napirendre kerül a Sargentini-jelentés. https:// www.napi.hu/magyar_gazdasag/odacsap_az_eu_ujra_napirendre_kerul_a_sargentini-jelentes.673011.html (utolsó letöltés ideje: 2020. 09. 30.).

Németh E. - Körmendi G. - Kiss B. (2011): Korrupció és nyilvánosság. Pénzügyi Szemle, 56(1): 57-65.

Népszava (2018): Bukhatjuk az EU-s pénzt a korrupt kormány miatt. 2018. 03.17.

Newell, J. - Bull, M. (2003): Introduction. In.: Bull, M. - Newell. N. (eds.): Corruption in Contemporary Politics. Palgrave, Basingstoke, 1-7.

North, D. C. - Wallis, J. S. - Webb, S. B. - Weingast, B. R. (2012): In the Shadow of Violence: Politics, Economics, and the Problems of Development. Cambridge, Cambridge University Press. 


\section{TANULMÁNY}

Origo (2018): Gyurcsány elszólta magát: bevallotta a korrupciót. https://www.origo. hu/itthon/20170913-gyurcsany-ferenc-korrupcio-dk-kormanyzati-beruhazasok.html (utolsó letöltés ideje: 2020. 09. 29.).

Papp Zs. (2019): Votes, money can buy. The conditional effect of EU Structural Funds on government MP's electoral performance. European Union Politics, 20(4): 543-561. doi: 10.1177/1465116519862875.

Pavao, N. (2018): Corruption as the Only Option: The Limits to Electoral Accountability. In: The Journal of Politics, 80 (3): 996-1010. doi: 10.1086/697954.

Peters, J. G. - Welch, S. (1980): The Effects of Charges of Corruption on Voting Behavior in Congressional Elections. American Political Science Review 74: 697708. doi: $10.2307 / 1958151$.

Petrétei J. (2007): A korrupció jellemzői és az ellene való küzdelem lehetőségei. Romániai Magyar Jogtudományi Közlöny. (1): 25-35.

Polyák G. (2018): Politikai kommunikáció a magyar választási kampányban. Mérték Médiaelemző Múhely https://mertek.atlatszo.hu/politikai-kommunikacioa-magyar-valasztasi-kampanyban/ (utolsó letöltés ideje: 2020. 09. 29.).

Révész S. (2008): Öncél és közcél. Élet és Irodalom 2008 (38).

Rosenstiel, T. - Mitchell, A. (2003): Thinking Clearly: Cases in Journalistic DecisionMaking. Columbia, Columbia University Press.

Rothstein, B. - Teorell, J. (2008): What Is Quality of Government? A Theory of Impartial Government Institutions. Governance. An International Journal of Policy, Administration, and Institution, 21(2), 165-190. doi: 10.1111/j.14680491.2008.00391.x.

Sartori, G. (1976): Parties and party systems. Cambridge, Cambridge University Press.

Schleiter, P. - Voznaya, A. M. (2014): Party system competitiveness and corruption. Party Politics 20(5): 675-686. doi: 10.1177/1354068812448690.

Sims, C. A. (1980): Macroeconomics and Reality. Econometrica 48: 1-48. doi: $10.2307 / 1912017$.

Szántó Z.- Tóth I. J. - Varga Sz. (2011): A korrupció társadalmi és intézményi szerkezete. Korrupciós tranzakciók tipikus kapcsolathálókonfigurációi Magyarországon. Szociológiai Szemle 21(3): 61-82.

Takács I. - Csapodi P. - Takács-György K. (2011): A korrupció mint deviáns társadalmi attitűd. Pénzügyi Szemle, 56(1): 26-42.

Tavits, M. (2007): Clarity of Responsibility and Corruption. American Journal of Political Science 51(1): 218-229. doi: https://doi.org/10.1111/j.1540-5907. 2007.00246.x. 


\section{TANULMÁNY}

Transparency International (2008): Korrupciós kockázatok az üzleti szektorban. Nemzeti Integritás Tanulmány". Második rész. Budapest.

Transparency International (2015): Az uniós források korrupciós kockázata Magyarországon. Budapest.

Transparency International (2017): A Korrupció Érzékelési Index 2017-ben. Budapest.

Treisman, D. (2000): The Causes of Corruption: A Cross-National Study. Journal of Public Economics 76: 399-457. doi: 10.1016/S0047-2727(99)00092-4.

Xezonakis, G. (2012): Corruption voting and political context: Testing the Micro Mechanisms. University of Gothenburg Working paper series 2012 (15).

Vásárhelyi M. (1988): A korrupció a közgondolkodásban. Szociológiai Szemle 1998 (4): 51-74.

Weschle, S. (2016): Punishing personal and electoral corruption: Experimental evidence from India. Research and Politics 3(2): 1-6. doi: 10.1177/ 2053168016645136

Winters, M. S. - Weitz-Shapiro, R. (2013): Lacking Information or Condoning Corruption: When Do Voters Support Corrupt Politicians? Comparative Politics 45 (4): 418-436. www.jstor.org/stable/43664074. 


\section{TANULMÁNY}

\section{A függelék: Az ADF-teszt bemutatása}

Az ADF-teszt az összes idősorra a következő regressziót becsüli:

$$
\Delta y_{t}=\mu+\alpha t+\gamma y_{t-1}+\sum_{i=1}^{p} y_{t-i+1}+\varepsilon_{t}
$$

ahol

$$
\gamma=-\left(1-\sum_{i=1}^{p} b_{i}\right)
$$

és

$$
\beta_{i}=-\sum_{j=1}^{p} b_{j}
$$

Az egyenletekben $\Delta y_{t}$ jelenti az idősor első differenciáját, $\mu$ az idősori átlagot, $\beta_{t}$ a késleltetett elsőrendű differenciák együtthatóit, $\varepsilon_{t}$ a regresszió fehérzaj maradéktagját és $b_{i}$ a maradéktag autoregresszív koefficienseinek értékét. Az ADF-teszt a $\gamma$ értékét vizsgálja és a következő hipotézispárt teszteli eltérő paramétermegkötések mellett:

$$
\begin{array}{ll}
H_{0}: & \gamma=0 \\
H_{1}: & \gamma \neq 0
\end{array}
$$

A teszt nullhipotézise, hogy a gamma paraméter értéke statisztikailag nem különbözik nullától, tehát az idősor nem stacioner. 


\section{TANULMÁNY}

\section{B függelék: VAR-modellek}

Ebben a függelékben bemutatjuk a VAR-modellek felépítését és Sims (1980) alapján a sokkok hatásának identifikálására szolgáló transzformációkat. A modellismertetést az impulzusválasz függvények, illetve a becslés bayes-i jellegének bemutatása követi.

\section{VAR-modellek identifikációja}

A vektor autoregressziók többegyenletes lineáris regressziók, amelyekben az endogén változók függvényei az összes endogén változó késleltetéseinek. Ebből fakadóan ez a modellcsalád képes idősorok együttes dinamikájának vizsgálatára.

Redukált modellnek nevezzük a változók hatásirányát nélkülöző modelleket. Habár a redukált modell a hagyományos legkisebb négyzetek módszerével statisztikai értelemben konzisztens és hatékony paraméterbecslést ad, nélkülözi azokat az elméleti restrikciókat, amelyekkel a politológiai irodalom alapján a modellünket úgymond „identifikálni” kell. Az identifikáció ebben az esetben azt jelenti, hogy feltevésünk szerint az EU-s források változása befolyásolja a kormánypárt támogatottságának - és a preferencia nélküliek változásának hatását, de ezek a változók nem hatnak vissza egyfajta multiplikátorként. Azaz úgy gondoljuk, hogy a források beáramlása valamilyen változást okoz a politikai preferenciákat kifejező idősorokban, de természetesen a preferenciák változása miatt nem kerül több vagy kevesebb forrás a gazdaságba.

A redukált modellt felírhatjuk a következő három késleltetést tartalmazó egyenletrendszerrel:

$$
\begin{aligned}
{\left[\begin{array}{c}
\Delta F U N D S_{t} \\
\Delta F I D_{t} \\
\Delta N P_{t}
\end{array}\right]=} & {\left[\begin{array}{c}
\gamma_{10} \\
\gamma_{20} \\
\gamma_{30}
\end{array}\right]+\left[\begin{array}{lll}
\gamma_{1,11} & \gamma_{1,12} & \gamma_{1,13} \\
\gamma_{1,21} & \gamma_{1,22} & \gamma_{1,23} \\
\gamma_{1,31} & \gamma_{1,32} & \gamma_{1,33}
\end{array}\right]\left[\begin{array}{c}
\Delta F U N D S_{t-1} \\
\Delta F I D_{t-1} \\
\Delta N P_{t-1}
\end{array}\right]+\ldots } \\
& \ldots+\left[\begin{array}{lll}
\gamma_{3,11} & \gamma_{3,12} & \gamma_{3,13} \\
\gamma_{3,21} & \gamma_{3,22} & \gamma_{3,23} \\
\gamma_{3,31} & \gamma_{3,32} & \gamma_{3,33}
\end{array}\right]\left[\begin{array}{c}
\Delta F U N D S_{t-3} \\
\Delta F I D_{t-3} \\
\Delta N P_{t-3}
\end{array}\right]+\left[\begin{array}{c}
\varepsilon_{\Delta F U N D S, t} \\
\varepsilon_{\Delta F I D, t} \\
\varepsilon_{\Delta N P, t}
\end{array}\right]
\end{aligned}
$$

A modell paramétereinél az első indexszám mutatja a mátrix számát, a második és harmadik pedig a sor- és oszlopszámot. Az egyenletrendszer így kompakt formában is felírva:

$$
\underset{3 \times 1}{\boldsymbol{X}_{t}}=\underset{3 \times 1}{\Gamma_{0}}+\underset{3 \times 3}{\Gamma_{1}} \boldsymbol{X}_{3 \times 1}+\underset{3 \times 3}{\Gamma_{2}} \boldsymbol{X}_{3 \times 1}+\underset{3 \times 3}{\Gamma_{3}} \boldsymbol{X}_{3 \times 1}+\underset{3 \times 1}{\epsilon_{t}}
$$

ahol $\boldsymbol{X}_{t}$ a változók és késleltetéseik $3 \times 1$-es vektorait, $\mathbf{G}_{\mathbf{0}}$ a tengelymetszetek $3 \times 1$-es vektorát, a $\boldsymbol{\Gamma}$-ák az együtthatók $3 \times 3$-as mátrixait és az $\mathbf{e}_{t}$ a hibatagok $3 \times 1$-es vektorát jelentik. 


\section{TANULMÁNY}

A maradéktagokról feltesszük, hogy várható értékük nulla:

$$
E\left[e_{t}\right]=0
$$

valamint a hibatagok között megengedett az időszakon belüli korreláció:

$$
E\left[e_{t} e_{t}^{\prime}\right]=\left[\begin{array}{ccc}
\operatorname{Var}\left(\varepsilon_{\Delta F U N D S}\right) & \operatorname{Cov}\left(\varepsilon_{\Delta F U N D S}, \varepsilon_{\Delta F I D}\right) & \operatorname{Cov}\left(\varepsilon_{\Delta F U N D S}, \varepsilon_{\Delta N P}\right) \\
\operatorname{Cov}\left(\varepsilon_{\Delta F I D}, \varepsilon_{\Delta F U N D S}\right) & \operatorname{Var}\left(\varepsilon_{\Delta F I D}\right) & \operatorname{Cov}\left(\varepsilon_{\Delta F I D}, \varepsilon_{\Delta N P}\right) \\
\operatorname{Cov}\left(\varepsilon_{\Delta N P}, \varepsilon_{\Delta F U N D S}\right) & \operatorname{Cov}\left(\varepsilon_{\Delta N P}, \varepsilon_{\Delta F I D}\right) & \operatorname{Var}\left(\varepsilon_{\Delta N P}\right)
\end{array}\right]
$$

azaz bármelyik kovariancia lehet nullától különböző.

A modell identifikált verzióját a strukturált formájának nevezzük. Feltesszük továbbá, hogy a változók nem csak késleltetve, hanem azonos időszakban is hatnak. Ekkor az egyenletrendszer a következőképp néz ki:

$$
\begin{gathered}
{\left[\begin{array}{ccc}
1 & \alpha_{12} & \alpha_{13} \\
\alpha_{21} & 1 & \alpha_{23} \\
\alpha_{31} & \alpha_{32} & 1
\end{array}\right]\left[\begin{array}{c}
\Delta F U N D S_{t} \\
\Delta F I D_{t} \\
\Delta N P_{t}
\end{array}\right]=\left[\begin{array}{l}
\beta_{10} \\
\beta_{20} \\
\beta_{30}
\end{array}\right]+\left[\begin{array}{lll}
\beta_{1,11} & \beta_{1,12} & \beta_{1,13} \\
\beta_{1,21} & \beta_{1,22} & \beta_{1,23} \\
\beta_{1,31} & \beta_{1,32} & \beta_{1,33}
\end{array}\right]\left[\begin{array}{c}
\Delta F U N D S_{t-1} \\
\Delta F I D_{t-1} \\
\Delta N P_{t-1}
\end{array}\right]+\ldots} \\
\ldots+\left[\begin{array}{lll}
\beta_{3,11} & \beta_{3,12} & \beta_{3,13} \\
\beta_{3,21} & \beta_{3,22} & \beta_{3,23} \\
\beta_{3,31} & \beta_{3,32} & \beta_{3,33}
\end{array}\right]\left[\begin{array}{c}
\Delta F U N D S_{t-3} \\
\Delta F I D_{t-3} \\
\Delta N P_{t-3}
\end{array}\right]+\left[\begin{array}{c}
u_{\Delta F U N D S, t} \\
u_{\Delta F I D, t} \\
u_{\Delta N P, t}
\end{array}\right]
\end{gathered}
$$

Látható, hogy a korábbi $\gamma$ paraméterek megváltoznak, így a strukturális modell paramétereit már $\beta$-val jelöljük.

A bal oldali változók, a strukturált modellben egy időszakon belül hatnak. A mátrixszorzást elvégezve az első egyenlet bal oldalán például a következő kifejezés látható:

$$
\Delta \text { FUNDS }_{\mathrm{t}}+\mathrm{a}_{12} \Delta \mathrm{FID}+\mathrm{a}_{13} \Delta \mathrm{NP},
$$

azaz a beáramló EU-s forrásokra azonos időszakban hatnak a politikai preferenciák változói, így a modell még nincs identifikálva. Ahhoz, hogy a változók az $\boldsymbol{X}_{\boldsymbol{t}}$ vektorbeli helyük sorrendjének irányában hassanak, az együtthatómátrix fődiagonálisán felüli értékeket nullával kell egyenlővé tenni:

$$
\alpha_{12}=\alpha_{13}=\alpha_{23}=0
$$

Ezek az úgynevezett restrikciók. A transzformációt Cholesky-felbontás segítségével elvégezve a következő mátrixot kapjuk: 


\section{TANULMÁNY}

$$
\boldsymbol{A}=\left[\begin{array}{ccc}
1 & 0 & 0 \\
\alpha_{21} & 1 & 0 \\
\alpha_{31} & \alpha_{32} & 1
\end{array}\right]
$$

Ennek inverze:

$$
\boldsymbol{A}^{-1}=\left[\begin{array}{ccc}
1 & 0 & 0 \\
-\alpha_{21} & 1 & 0 \\
-\alpha_{31}+\alpha_{21} \alpha_{32} & -\alpha_{32} & 1
\end{array}\right]
$$

A strukturált egyenlet kompakt formája ekkor a következő:

$$
A X_{t}=B_{0}+B_{1} X_{t-1}+B_{2} X_{t-2}+B_{3} X_{t-3}+u_{t}
$$

Mivel a mátrix és inverzének szorzata az egységmátrix, így mindkét oldalt beszorozva az inverzzel a strukturális egyenlet a következő:

$$
X_{t}^{=}=A^{-1} B_{0}+A^{-1} B_{1} X_{t-1}+A^{-1} B_{2} X_{t-2}+A^{-1} B_{3} X_{t-3}+A^{-1} u_{t}
$$

A becslési probléma lényege, hogy a „látható” redukált egyenlet becslésekor a $\boldsymbol{\Gamma}$ mátrixok elemeit kapjuk, de ezek nem azonosak a valós, „nem látható” B strukturális egyenlet mátrixainak paramétereivel. Azonban a redukált egyenlettel összevetve a strukturális együtthatók mátrixait és a hibatagok vektorát, azokat egymással megfeleltethetjük:

$$
\begin{aligned}
\Gamma_{0} & =A^{-1} B_{0} \\
\Gamma_{1} & =A^{-1} B_{1} \\
\Gamma_{2} & =A^{-1} B_{2} \\
\Gamma_{3} & =A^{-1} B_{3} \\
e_{t} & =A^{-1} u_{t}
\end{aligned}
$$

és meghatározhatjuk a paramétereket. Az egyenletrendszerek alapján a redukált és a strukturális egyenlet hibatagjai közötti összefüggés:

$$
\left[\begin{array}{c}
\varepsilon_{\triangle F U N D S, t} \\
\varepsilon_{\Delta F I D, t} \\
\varepsilon_{\Delta N P, t}
\end{array}\right]=\left[\begin{array}{ccc}
1 & 0 & 0 \\
-\alpha_{21} & 1 & 0 \\
-\alpha_{31}+\alpha_{21} \alpha_{32} & -\alpha_{32} & 1
\end{array}\right]\left[\begin{array}{c}
u_{\Delta F U N D S, t} \\
u_{\triangle F I D, t} \\
u_{\Delta N P, t}
\end{array}\right]
$$

amit külön-külön felírva a következő egyenleteket kapjuk: 


\section{TANULMÁNY}

$$
\begin{aligned}
\varepsilon_{\triangle F U N D S, t} & =u_{\triangle F U N D S, t} \\
\varepsilon_{\triangle F I D, t} & =-\alpha_{21} u_{\Delta F U N D S, t}+u_{\Delta F I D, t} \\
\varepsilon_{\Delta N P, t} & =\left(-\alpha_{31}+\alpha_{21} \alpha_{32}\right) u_{\Delta F U N D S, t}-\alpha_{32} u_{\Delta F I D, t}+u_{\Delta N P, t}
\end{aligned}
$$

Tehát a becsült három egyenlet hibatagjai közötti kapcsolat az A együttható mátrix elemeinek ismeretében megoldható és a vektor autoregresszió identifikált. Amennyiben például az EU-s támogatásokat pozitív sokk éri, az hat a politikai preferenciák változásának hibatagjaira és az autoregresszív tagok miatt a változókra is. A kormánypárt támogatottságának változását érő sokk pedig szintén hat a preferencia nélküliek arányának változására. A két hatás azonban visszafelé már nem érvényesül. A preferencia nélküliek arányát érő sokk nem hat a többi idősorra.

\section{Impulzusválasz függvények}

Az a impulzusválasz függvények a VAR-modellek grafikus reprezentációjára szolgálnak. Mivel egy VAR-modell rendszeresen túlparaméterezett az egyenletek nagy száma miatt, így azt nem lehet a hagyományos egy egyenletes regressziókhoz hasonlóan paraméterenként értelmezni.

Az IRF-ek egy adott változó maradéktagjában bekövetkező egy egységnyi sokk hatását mutatják meg az összes endogén változóra a vektor autoregresszióban (Enders, 1995). Az IRF-ek előállításához az eredeti strukturális egyenlethez kell visszanyúlni:

$$
A X_{t}=B_{0}+B_{1} X_{t-1}+B_{2} X_{t-2}+B_{3} X_{t-3}+u_{t}
$$

A Wold-tétel alapján minden autoregresszív modell átalakítható a hibatagok végtelen számú késleltetésének lineáris kombinációjává, így a strukturális egyenlet a következő alakban is felírható:

$$
\boldsymbol{X}_{t}=\boldsymbol{\mu}+\sum_{i=0}^{\infty} c_{i} \boldsymbol{u}_{i-t}
$$

ahol a $\boldsymbol{\mu}$ paramétervektor jelenti a változók hosszútávú átlagait, míg a $\boldsymbol{c}_{\boldsymbol{i}}$ együtthatók vektora a késleltetett sokkok hatását az idősorokra. A transzformáció segítségével így egy identifikált vektor autoregresszióban a $\boldsymbol{c}_{\boldsymbol{i}}$ paraméterek segítségével fel tudjuk rajzolni a sokk hatását az endogén változókra. 


\section{TANULMÁNY}

\section{Mitől lesz egy becslés bayes-i?}

A hagyományos frekventista statisztika során a paraméterbecslések valamilyen analitikus vagy a $P(x \mid \theta)$ likelihood függvényen alapuló numerikus becslés során állíthatóak elő. A VAR-modellek esetében mindkét megoldás járható út, a modell paramétereit egyaránt becsülhetjük analitikus legkisebb négyzetek módszerével, vagy maximum likelihood eljárással.

Mindkét eljárás megköveteli a maradéktagok normalitásának feltételét, ami nélkül a maradéktagok feltételes varianciája nem állandó és a frekventista tesztek nem érvényesek rájuk. A modellépítés során a VAR-rendszerek jellemzően túlparaméterezettek és így nagy megfigyelésszámot igényelnek, hogy a t-statisztikák szabadságfoka elég nagy legyen a normális közelítéshez. Ez a helyzet áll fenn a 69 adatpontot tartalmazó korrupciós modellünk esetén is.

Ebből az okból a frekventista becslést bayes-ivel kell helyettesíteni. A két statisztikai tradíció között a fő különbség, hogy a frekventista iskola a likelihood függvényből indul ki és felteszi, hogy a mintavétel eredményeként kapott értékeket egy valamilyen $\theta$ sokasági paraméterrel leírható folyamat generálja. A bayes-i iskola ezzel szemben nem tekinti fixnek a $\theta$ értékét és úgy gondolja, hogy azt egy $P(\theta)$, úgynevezett prior befolyásolja.

Az összefüggés a Bayes-tételen alapul, amit egyszerű formában a következőképpen írhatunk fel:

$$
P(\theta \mid x) \propto P(\theta) P(x \mid \theta)
$$

A 19. egyenlet alapján a posteriori eloszlás arányos a likelihood és a prior szorzatával. A prior megválasztása alapulhat szakértői ismereteken, de egyre gyakrabban az ebben a tanulmányban is alkalmazott Monte Carlo-szimulációk alapján történik. A BVAR-modell becslése során használt analitikus Minnesota, analitikus konjugált normális - Wishart és független prior-poszterior priorok a Monte Carlo-szimulációk segítségével képesek pótolni a kis mintából eredő frekventista hiányosságokat. 
www. metszetek.unideb.hu

\section{TANULMÁNY}

\section{C függelék: Pontbecslések posteriori eloszlásai és IRF-ek}

8. ábra. Prediktív sűrűség: Analitikus Minnesota prior
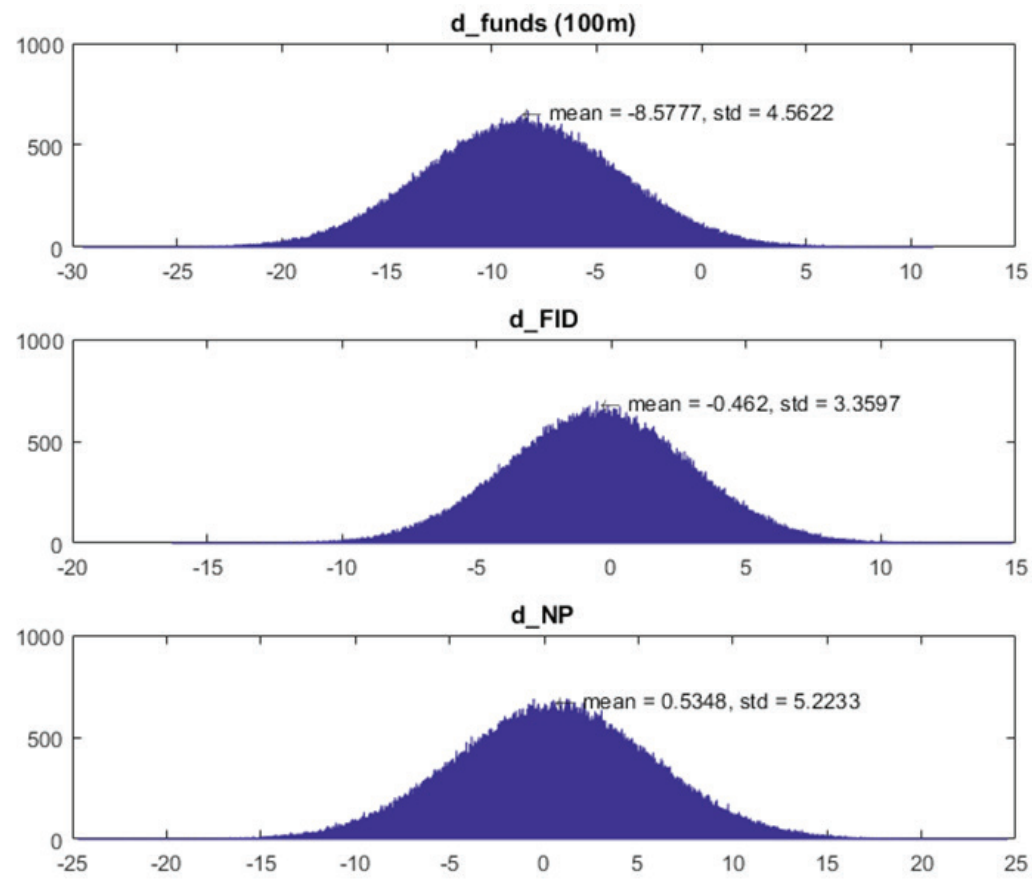
www. metszetek.unideb.hu

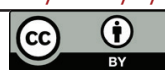

\section{TANULMÁNY}

9. ábra. Prediktív sűrűség: Analitikus konjugált normális - Wishart prior
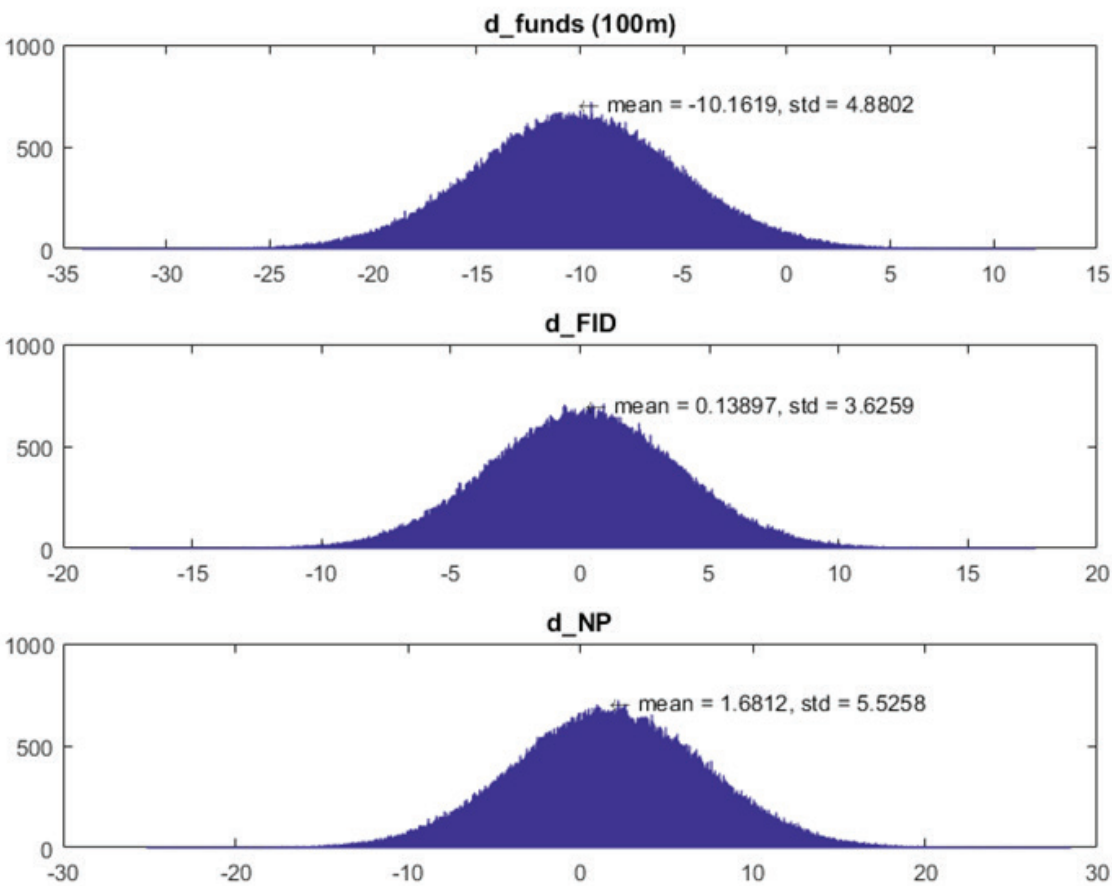
www. metszetek.unideb.hu

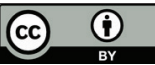

\section{TANULMÁNY}

10. ábra. Prediktív sűrüség: Független prior-poszterior, Minnesota (Gibbs sampling)
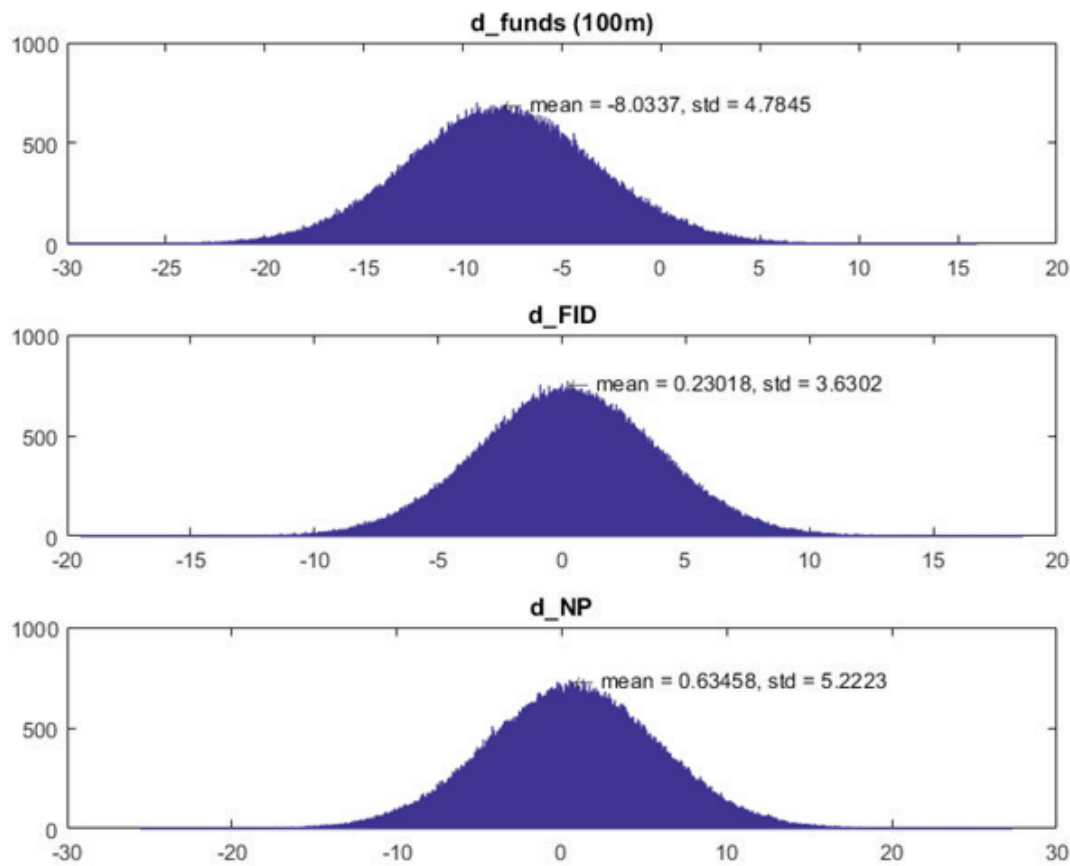
www. metszetek.unideb.hu

\section{TANULMÁNY}

11. ábra. IRF: Analitikus Minnesota prior
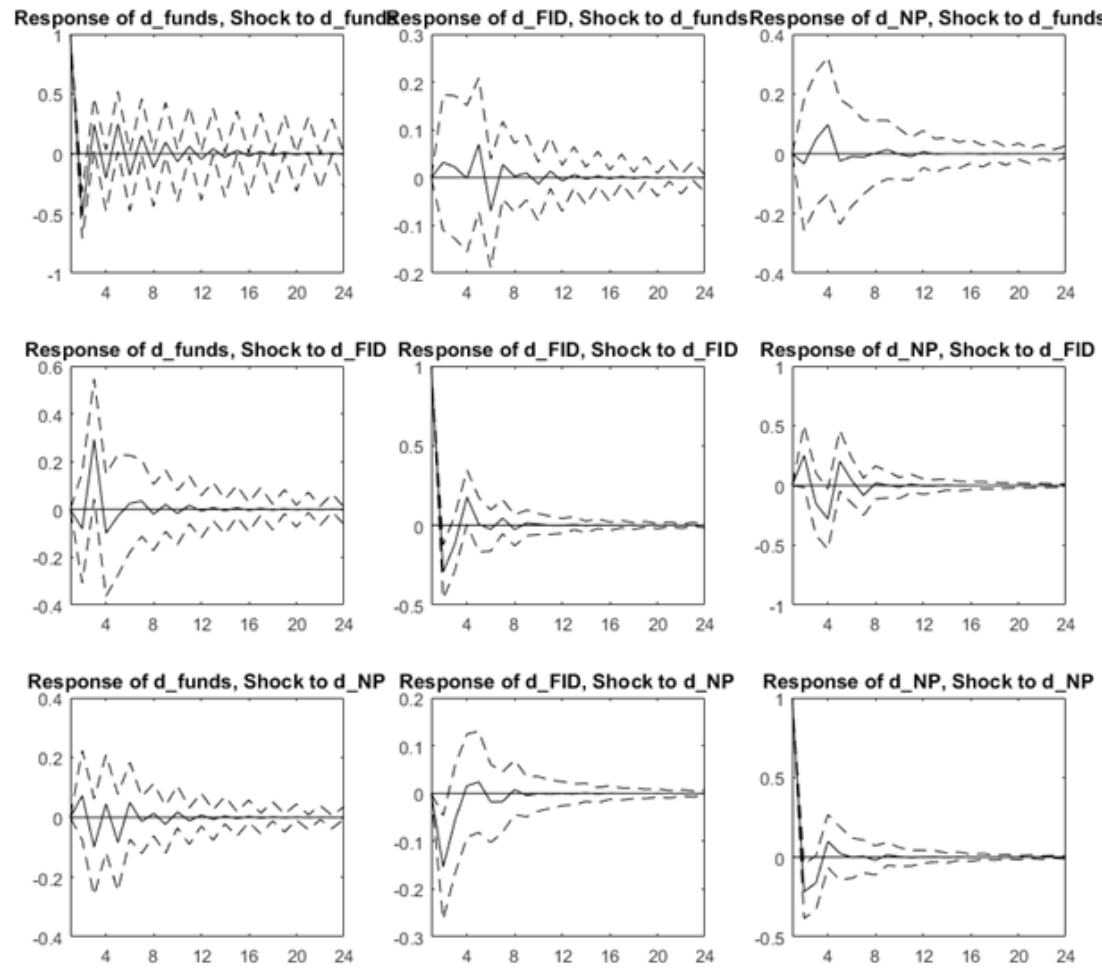
www. metszetek.unideb.hu

\section{TANULMÁNY}

12. ábra. IRF: Analitikus konjugált normális - Wishart prior
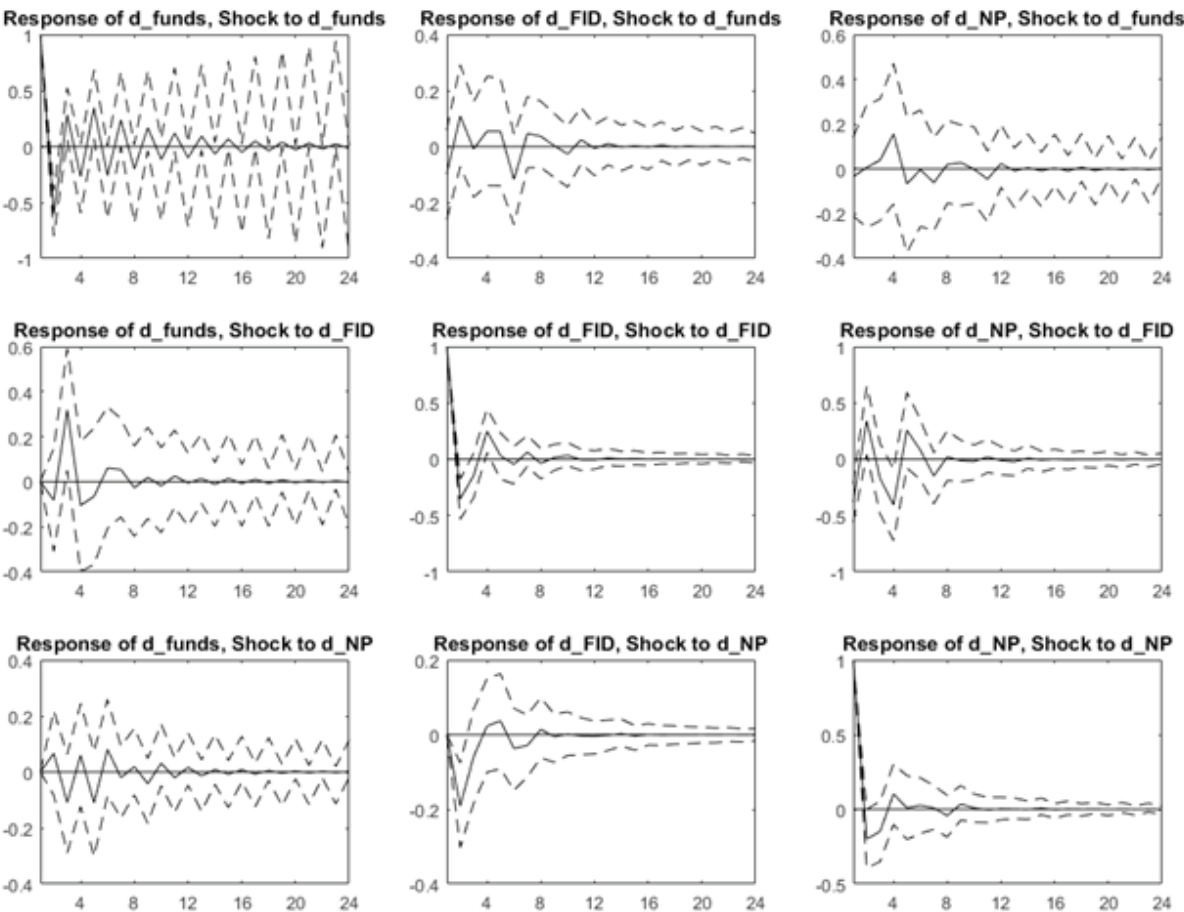
www. metszetek.unideb.hu

\section{TANULMÁNY}

13. ábra. IRF: Független prior-poszterior, Minnesota (Gibbs sampling)
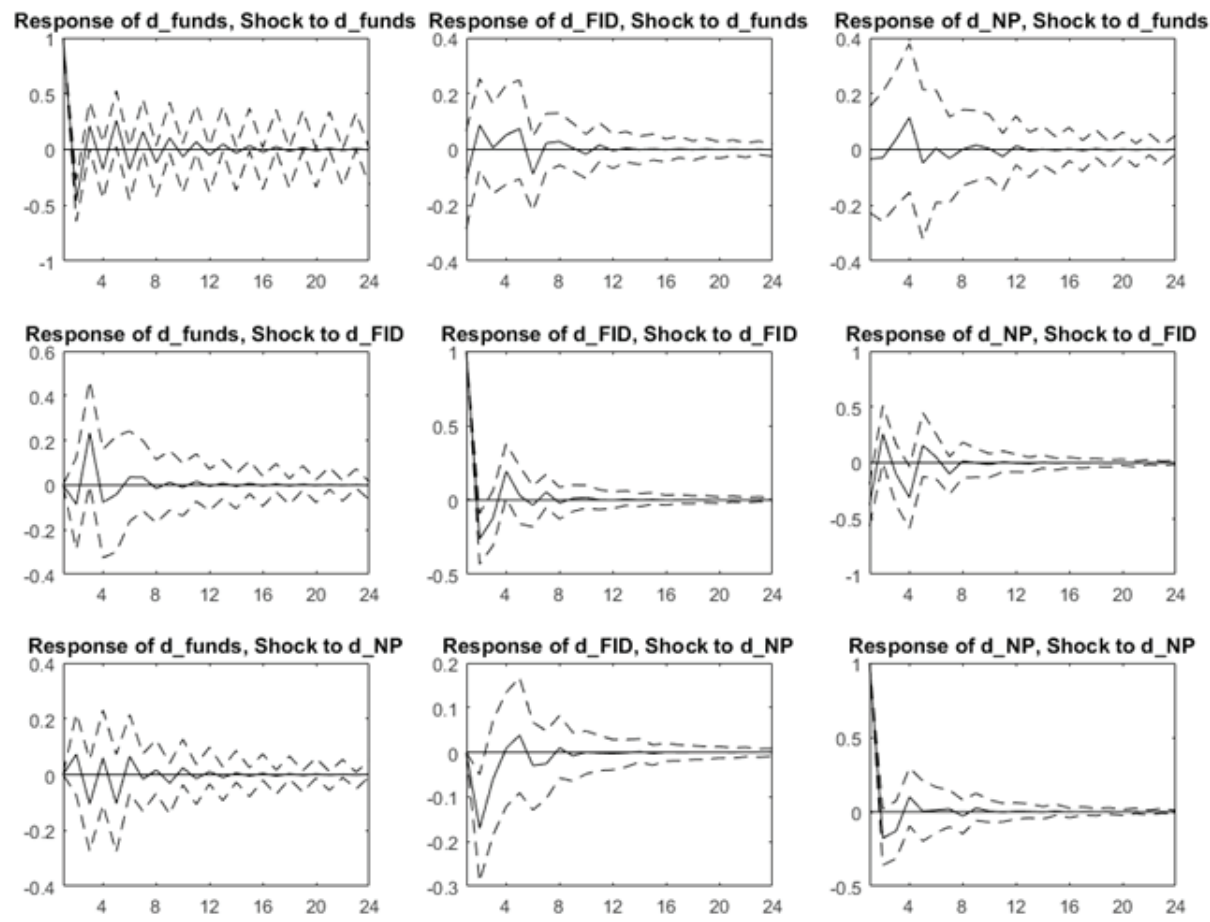